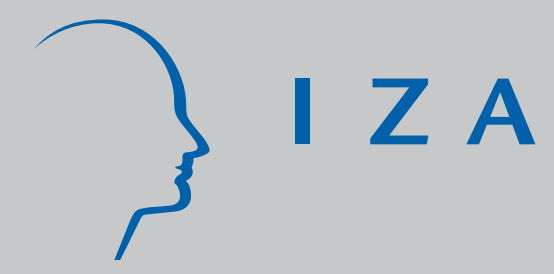

IZADP No. 1565

Mind the Gap:

Unemployment in the New EU Regions

Anna Maria Ferragina

Francesco Pastore

April 2005 


\title{
Mind the Gap: \\ Unemployment in the New EU Regions
}

\author{
Anna Maria Ferragina \\ CNR and University of Rome "Tor Vergata" \\ Francesco Pastore \\ University of Naples II \\ and IZA Bonn
}
Discussion Paper No. 1565
April 2005

\author{
IZA \\ P.O. Box 7240 \\ 53072 Bonn \\ Germany \\ Phone: +49-228-3894-0 \\ Fax: +49-228-3894-180 \\ Email: iza@iza.org
}

\begin{abstract}
Any opinions expressed here are those of the author(s) and not those of the institute. Research disseminated by IZA may include views on policy, but the institute itself takes no institutional policy positions.

The Institute for the Study of Labor (IZA) in Bonn is a local and virtual international research center and a place of communication between science, politics and business. IZA is an independent nonprofit company supported by Deutsche Post World Net. The center is associated with the University of Bonn and offers a stimulating research environment through its research networks, research support, and visitors and doctoral programs. IZA engages in (i) original and internationally competitive research in all fields of labor economics, (ii) development of policy concepts, and (iii) dissemination of research results and concepts to the interested public.
\end{abstract}

IZA Discussion Papers often represent preliminary work and are circulated to encourage discussion. Citation of such a paper should account for its provisional character. A revised version may be available directly from the author. 
IZA Discussion Paper No. 1565

April 2005

\section{ABSTRACT}

\section{Mind the Gap: Unemployment in the New EU Regions}

The paper surveys the theoretical and empirical literature on regional unemployment during transition in Central and Eastern Europe. The focus is on Optimal Speed of Transition (OST) models and on comparison of them with the neoclassical tradition. In the typical neoclassical models, spatial differences essentially arise as a consequence of supply side constraints and institutional rigidities. Slow-growth, high-unemployment regions are those with backward economic structures and constraints on factors mobility contribute to making differences persistent. However, such explanations leave the question unanswered of how unemployment differences arise in the first place. Economic transition provides an excellent testing ground to answer this question. Prefiguring an empirical law, the OST literature finds that the high degree of labour turnover of high unemployment regions is associated with a high rate of industrial restructuring and, consequently, that low unemployment may be achieved by implementing transition more gradually. Moreover, international trade, FDI and various agglomeration factors help explain the success of capital cities compared to peripheral towns and rural areas in achieving low unemployment.

JEL Classification: J6, P2, R1, R23

Keywords: regional unemployment, structural change, labour turnover, optimal speed of transition, Central and Eastern Europe

Corresponding author:

Francesco Pastore

University of Naples II

Salita Tarsia 74

80135 - Napoli

Italy

Email: fpastore@unina.it 


\section{Mind the Gap: Unemployment in the new EU regions}

\section{Introduction}

The aim of this paper is to survey the theoretical and empirical literature on regional unemployment persistence in transition countries. The main focus of the analysis will be Central and Eastern Europe (CEE), rather than the republics of the CIS or of the Asian continent, though some reference to these last economies will be made. The analysis will be mainly based on the eight new EU members, plus Bulgaria and Romania, which should join the EU in 2007.' This is a very important and topical issue not only for a full understanding of the unprecedented transition from a centrally planned to a market allocation system, but also considering the commitment of the European Union on reducing regional unemployment differences.

This literature raises the following questions: In what respect does regional unemployment in transition countries differ from that in other mature market economies? Do we need a specific theoretical and methodological framework to understand such differences? Or, conversely, are the standard explanations sufficient for the purpose? The answers to these questions can be synthesised as follows. The determinants of regional unemployment in emerging market economies in the post-Soviet bloc differed from those in mature market economies especially in the early stages of transition. Massive and prolonged structural change, rarely experienced in mature capitalist economies, drove the process. A different pace of restructuring and the ability to attract foreign capital made some regions' economic transformation fast, successful and relatively painless, while less successful regions started to lag behind. These differences persisted over time for three main reasons: first, restructuring is still going on; second, for many years foreign capital continued to concentrate in successful regions; third, various forms of labour supply rigidity impeded the process of adjustment. These rigidities stem from low labour mobility, hindered by high housing and transportation costs, rather than by low wage differentials.

Within the group of the Central and Eastern European Countries (CEECs), especial attention will be paid to Poland for two main reasons: first, this country is the largest and most populated one and displays dramatic and persistent spatial differences; second, the empirical literature has focused especially on Poland, also thanks to the availability of good quality data.

Just prior to the transition process, in 1989, the official statistics recorded sizeable numbers of vacancies in most CEECs. Kornai (1992) explains chronic labour shortage as a normal outcome of the socialist system with its emphasis on forced growth via extensive production methods used by the state to absorb the entire available labour surplus. Mass unemployment 
erupted in most CEECs in 1990, soon after the beginning of the reform process that intended to lead the centrally planned socialist system to a market driven capitalist one.

Unemployment immediately appeared to be uneven across regions in all CEECs, and remarkably persistent. $^{2}$ Regional unemployment persistence in transition countries is particularly interesting for at least two reasons. First, transition countries provide an example of the sudden emergence of regional unemployment, as in a quasi-natural experiment. Consequently, part of the literature has focused not only on impediments to the adjustment process due, for instance, to supply side rigidities, these being the usual suspects for regional unemployment persistence in the neoclassical strand of the literature, but also on the causes of the emergence of regional unemployment differentials. This requires studying the process of structural change and the reasons why it may differ across regions.

Some applied studies seem to confirm the theoretical predictions of the benchmark Optimal Speed of Transition (OST) model (Aghion and Blanchard, 1994) that structural change largely explains regional unemployment in the 1990s. The relationship among industrial restructuring due to the reform process, a high level of labour turnover, and the local unemployment rate seems to find empirical support against the alternative hypothesis that unemployment differentials are due to differences in the job finding rate and in the duration of unemployment spells. When unemployment is positively related to workers' reallocation across regions, spatial unemployment differentials increase and the main reason is a different degree of industrial change; whereas when workers' reallocation is constant across regions with different unemployment rates, spatial unemployment differences are already persistent, and this is due to the slow process of job creation as well as to the sluggishness of the adjustment process. This finding suggests the existence of an empirical law which is able to disentangle the case when unemployment is due to a high degree of structural change and when it is due to labour market rigidities, which warrants further investigation in the case of non-transition countries.

For all these reasons, although the literature on supply side rigidities is large and important, the main focus of this survey will be on studies which assess the role of industrial change in shaping the regional distribution of unemployment. This seems to be the most innovative and interesting contribution of the OST literature to the understanding of the determinants of spatial unemployment. As Elhorst (2003) shows, in fact, the debate on regional unemployment in mature market economies as often focused on net, rather than on gross employment changes.

The rest of this paper is organised as follows. Section Two outlines the neoclassical explanations of regional unemployment and attempts to explain why the OST literature initially departed from them. Section Three provides an overview of the benchmark OST model developed by Aghion and Blanchard (1994) and the successive model by Boeri (2000). Section 
Four highlights some testable implications of the OST models and reviews the attempts to test the validity of the OST model. Section Five focuses on the impact of economic integration and capital flows from abroad on local labour markets. Some concluding remarks follow.

\section{The neoclassical approach to regional unemployment}

Within the neoclassical strand of the literature, scholars typically explain regional unemployment in terms of a failure of the adjustment process to absorb asymmetric shocks due to supply side rigidities, and they point to flexible labour markets as the solution enabling high unemployment regions to catch up with the rest of the country.

According to Marston (1985), who provides perhaps one of the clearest examples of a neoclassical model of regional unemployment, the factors behind local unemployment are "weak labour demand" and "economic and social barriers [that] may separate local labour markets". He suggests that regional unemployment may be either a dis-equilibrium or an equilibrium phenomenon.

\footnotetext{
Economic and social barriers may separate local labour markets. If these barriers restrict mobility severely, then weak labour demand in one geographic area will raise the unemployment rate there above its level in areas with stronger labour demand. On the other hand, if mobility is relatively free between areas, then strong labour demand elsewhere will leave workers away from a high unemployment area. Excess labour in the area will vanish quickly unless workers are compensated in some way that induces them to remain there voluntarily. Any persistent geographical unemployment differentials, then, are not evidence of uneven labour demand, but reflections of workers' underlying preferences for certain areas (Marston, 1985, p. 57).
}

The two factors stressed by Marston (ibid.) as the main causes of regional unemployment well summarise the neoclassical view of regional unemployment, its strength and weaknesses. Local unemployment is due to some unspecified shortage of labour demand and to barriers hindering the adjustment process which smoothes such differences. However, given that labour demand shortage is left essentially unexplained in the model, the entire focus is on the adjustment process. ${ }^{3}$

This view of regional unemployment is especially unsatisfactory in the case of transition countries, where regional unemployment differences emerged from nothing at the outset of transition. Moreover, as argued in Bornhorst and Commander (2004), all the existing models of regional unemployment, including the synthesis by Blanchard and Katz (1992), have as basic assumption that of equilibrium, which is untenable for transition countries undergoing massive structural change. They note: "The first decade of transition was marked by profound structural adjustments not directly comparable to the demand shocks lying behind the dynamics outlined 
above [in the Blanchard and Katz model]. This makes identification of equilibrium conditions a largely futile exercise" (p.3).

It is therefore not surprising that the literature of the early 1990s on regional unemployment in CEE focused more on the primary factors of uneven spatial unemployment, namely the factors weakening local labour demand, than on the factors hindering the adjustment process. Only at a later stage, particularly at the end of the 1990s, did the focus shift to study the supply constraints on the adjustment process.

\section{The OST literature and regional unemployment}

The literature on regional unemployment in transition countries does not provide a specific theoretical framework to explain spatial unemployment differentials. However, the OST literature ${ }^{4}$ does provide a framework in which to consider the reasons for the emergence of unemployment during transition. We suggest that such a framework can also be used to form predictions about regional unemployment. The first wave of the OST literature points to local labour demand shifts as factors responsible for high spatial unemployment. The following waves of the OST literature can be combined with the neoclassical tradition to provide insights into the factors hindering the adjustment to evenly distributed unemployment rates.

\subsection{Economic transition as a process of structural change}

There are various theoretical frameworks within which to consider economic transition from a centrally planned to a market economy. ${ }^{5}$ However, the most widely used approach is to describe economic transition as essentially a regime change from an allocation system based on central planning to one based on market forces: a systemic process of liberalisation affecting the formation of prices, the rules of national and international trade and the private initiative drives this change. ${ }^{6}$

A well-known representation depicts transition as a move towards the production frontier from a point below it, say from point $P$ to point $E_{0}$ in Figure 1 . This representation immediately conveys the idea that a centrally planned economy operates with a sizeable waste of resources and that the move to a decentralised decision-making process implies increasing productivity. Moreover, on the assumption that state firms only produce within a centrally planned economy, the liberalisation process implies a shift of resources allocation primarily from the state to the private sector, but also from agriculture and manufacturing to services and from large to small firms. In Figure 1, this means a reallocation from the production of good $a$, on the horizontal 
axis, to that of good $b$, on the vertical axis. Transition should therefore bring with it a sectoral reallocation as well as a substantial efficiency gain. Moreover, in the long run, it is supposedly able to push the production frontier upwards, favouring private initiative and investment. The long-run equilibrium would therefore be $E_{1}$.

Figure 1. Transition as a change of the allocation system

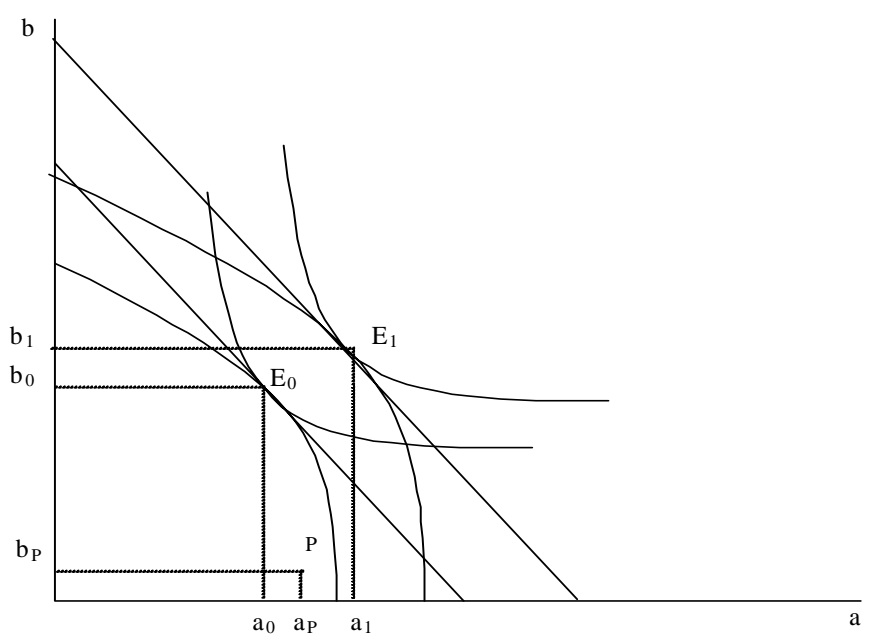

Within this general equilibrium framework, however, it is not possible to predict the time required for the process to come about, because transition is supposedly instantaneous. Nonetheless, particularly in the early stages of the transformation process, the speed of transition and of the ensuing reallocation process were widely debated issues. At what speed should the economy move from point $P$ to point $E_{0}$ in Figure 1?

The eternal opposition in economics between advocates of free trade and interventionists took the form of debate on whether a shock therapy would be more effective than gradual transformation. Answering the question on the timing of transformation also requires examination of the frictions that may slow the transformation process down. Are these the same frictions as considered by any model of sectoral reallocation? Or are there specific transitional frictions to be taken into account?

\subsection{Transition through workers' reallocation}

In the early stages of transition, there were two salient facts that theoreticians had to explain with their models: the dramatic fall in output, and burgeoning mass unemployment, which appeared to be at odds with the general equilibrium description of economic transition as a move to a more efficient allocation system. To explain these two features of transformation, 
Aghion and Blanchard (1994) develop a model (henceforth ABM), which has become a benchmark. ${ }^{7}$ They chose a setting in which the dynamics is essentially driven by costly sectoral adjustment, and particular assumptions are made concerning the specificity of the event considered. $^{8}$

Blanchard (1997, p. 25) describes transition as shaped by two main mechanisms: reallocation and restructuring. A reallocation of resources, especially labour, between the state and the private sector is the main driving force behind transition. The cause of reallocation is restructuring and a two-sector framework is chosen to describe it. Production is essentially undertaken by a dominant but shrinking state sector ( $s$ ) and by a buoyant new private sector $(p)$. Labour productivity is higher in the private sector $(y)$ than in the state sector $(x)$ by a constant amount, $\theta$, so that $y-x=\theta$. Normalising the number of workers to one, the equilibrium condition of the labour market is:

$$
\mathrm{N}_{\mathrm{p}}+\mathrm{N}_{\mathrm{s}}+\mathrm{U}=1 \text {, }
$$

where $\mathrm{U}$ is the number of unemployed. ${ }^{9}$ The separation rate from the state sector can be thought of as exogenous (decided by the government) ${ }^{10}$ and equal to $s$ (like the speed of restructuring)

$$
\hat{N}_{s}=\frac{d N_{s}}{d t}=-s
$$

Private job creation $\left(\hat{N}_{P}\right.$, or $H$ ) is a function $a$ of the profit firms make in the private sector. Profits equal the difference between labour productivity in the private sector and the cost of labour, including wages, $w$, and the tax levied on wages, essentially to pay unemployment benefits, $z$ :

$$
\hat{N}_{P}=H=\frac{d N_{P}}{d t}=a[y-(w+z)]
$$

Note that $\hat{N}_{S}$ is strictly negative and $\hat{N}_{P}$ is strictly positive. In other words, the state sector only destroys jobs and the private sector only creates jobs. ${ }^{11}$

Wages are determined according to efficiency wage considerations, like in a simplified Shapiro and Stiglitz type of wage equation:

$$
w=b+c\left(r+\frac{H}{U}\right)
$$

where wages in the private sector are set on the basis of labour market conditions at a level that equals the unemployment benefit, $b$, plus a given share, $c$, of the sum of the interest rate and the probability of being hired in the private sector. Unemployment reduces wages, and therefore fosters private sector growth. 
In addition, the overall expenditure on benefits, given by a time-invariant per capita level of unemployment benefits times the stock of the unemployed should equal the tax levied on wages times the number of workers employed in the state and in the private sector, or:

$$
b U=z(1-U)
$$

It is apparent from [3] and [5] that unemployment also has adverse effects on private job creation, because it increases the level of taxes per worker, $z$, thus reducing the level of profits, the only source of financing for private firms. ${ }^{12}$

Consider now the conditions under which the optimal speed of transition can be obtained. Unemployment is increasing (decreasing) if the inflow into it exceeds (is lower than) the outflows out of it. The inflow to unemployment is a given share, $s$, of state employment and the outflow from unemployment is private job creation. Analytically:

$$
\hat{U}=\frac{d U}{d t}=s(1-\lambda)-H \text {, with } U_{0}=1-N_{S}-N_{P}
$$

In turn, as already noted, private job creation is affected by unemployment through two main channels: wages and taxes. This effect is obtained by substituting the values of wages from [4] and the value of the per worker tax [5] into the equation for the hiring rate, [3]:

$$
H=\frac{a U}{U+a c}\left[y-r c-\left(\frac{1}{1-U}\right) b\right]
$$

Equation [7] summarises the double effect of unemployment on the hiring rate. Figure 2 plots the hiring rate as a bell-shaped function of unemployment. The separation rate is a straight line. The evolution of unemployment depends on the separation rate: when this is above (below) the hiring rate, unemployment increases (shrinks).

When the speed of restructuring is too fast, actual separations exceed the maximum hiring rate $\left.\left(\hat{N}_{S}\right\rangle \hat{N}_{P}^{\text {Max }}\right)$ and private job creation is unable to absorb the workers laid off by the state sector. Unemployment increases steadily, eventually reaching such a high level that the fiscal burden it generates causes the reforms to fail. This suggests that the reform should be gradual. The most common case, however, is when $\hat{N}_{S}\left\langle\hat{N}_{P}^{\operatorname{Max}}\right.$. In this event, two equilibrium unemployment levels are possible, of which only $A$ is stable. For any level of unemployment lower (higher) than $U_{A}$, the separation rate exceeds (is lower than) the hiring rate and unemployment increases (shrinks). Conversely, if unemployment reaches the level $U_{B}$, the negative effect on taxes offsets the positive effect on wages, which causes the reforms to fail. 


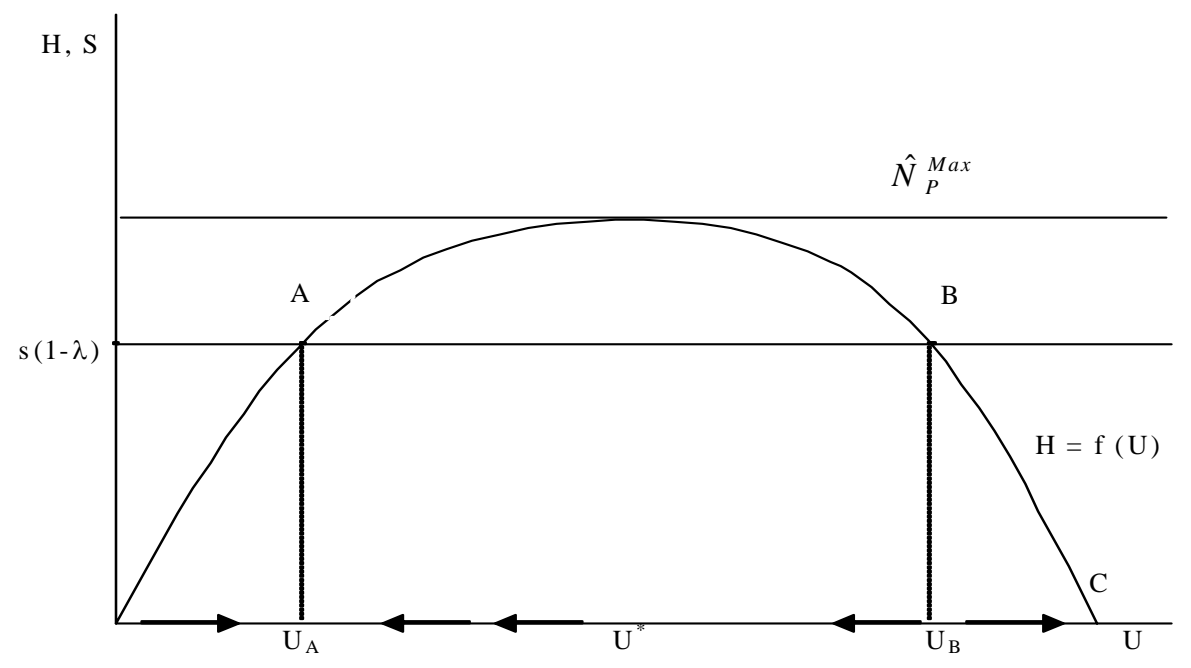

\subsection{The predictions of the ABM regarding local unemployment}

This sections' aim is to speculate on the benchmark OST model to find possible explanations for regional unemployment differentials. Assuming that the model applies also at a regional level, there seem to be two possibilities. According to a first hypothesis, high unemployment regions are those regions that reach the second unstable equilibrium, namely point $B$ in Figure 3. These regions can be conceived as experiencing an unsuccessful transition process, with a too high separation rate at the beginning of transition, so that the unemployment rate exceeds its equilibrium level. The fact that the country is posited on point A weakens the feedback mechanisms, which would lead the reforms to fail, since the speed of reforms is decided centrally. As a consequence, the regional dispersion of unemployment remains, with some tensions from the periphery to the centre being absorbed over time. Unemployment persistence can be considered the consequence of a low job creation rate and a high share of long-term unemployment, rather than of a high separation rate.

A testable hypothesis with which to verify whether this is the case assumes that the separation and hiring rates - or their sum, the rate of labour turnover - are constant across regions with different unemployment rates. We shall call this 'Hypothesis One' or $H_{1}$.

An alternative hypothesis - which we shall call $H_{0}$ - is that the regional dispersion of unemployment is shaped by a persistently different degree of worker turnover, and restructuring, across regions. In other words, there is no national job separation rate, but rather different rates of job separation and hence of unemployment across regions. Figure 3 illustrates this idea as well. Regional unemployment can be conceived as an equilibrium phenomenon 
which disappears only when transition comes to an end. Once the local separation rate has reached a given level, it tends to persist, and also determines the rate of unemployment. The hypothesis $H_{0}$, therefore, implies that the rate of labour turnover should increase with the unemployment rate.

Figure 3. The benchmark OST model and regional unemployment

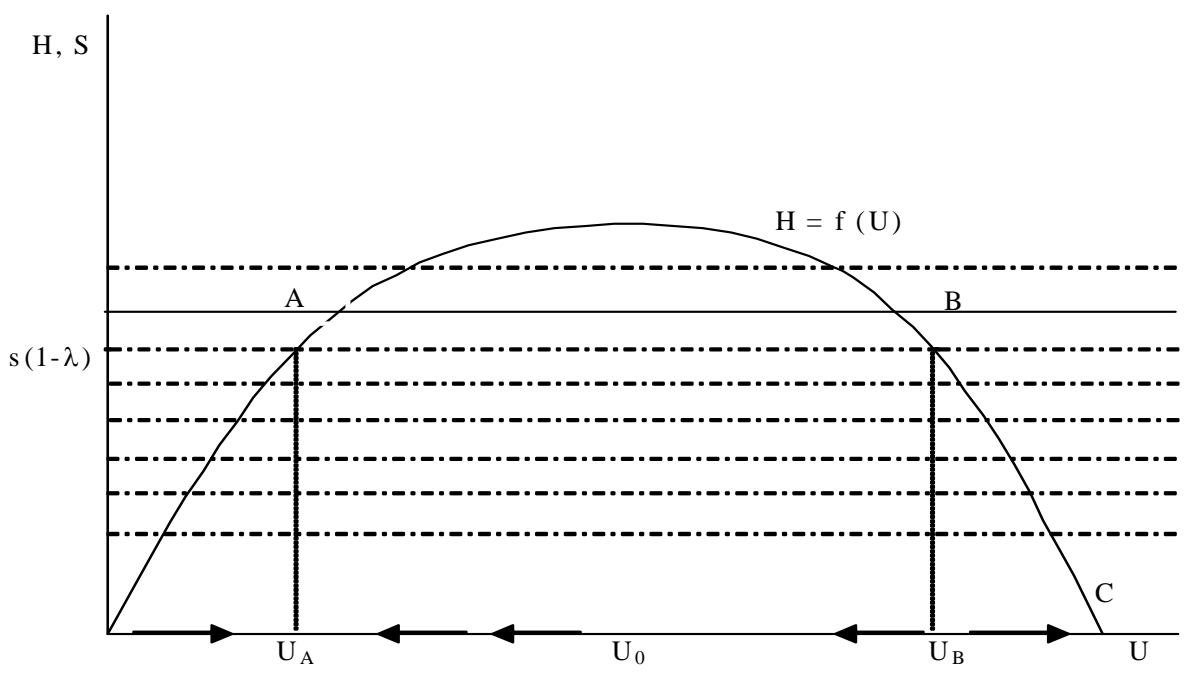

The policy implications of these alternative hypotheses are partly different. Whilst a low job finding rate essentially indicates the need for supply side policies in favour of the long-term unemployed, namely increasing labour market flexibility and/or educational reforms and active labour market policy on a large scale, $H_{0}$ also requires interventions on the demand side. For instance, assuming that the government is able to do so, it should reduce the rate of separation and/or increase the life expectancy of private businesses in the high unemployment regions.

Notice that, under $H_{1}$, the separation rate in some regions is high only at the beginning of the transformation process, whereas under $H_{0}$ it is persistently high. Why transition happens at a different speed at a local level? One possibility that we may easily exclude is that it is the policy-maker who wishes to implement reforms at a different speed across regions. Another possibility is that the stronger the power of the unions, the lower the separation rate in the area. Unfortunately, information on union power is lacking in all transition countries, so that this hypothesis is difficult to test. In addition, union power is itself a negative function of the unemployment rate, generating endogeneity problems.

A third possibility is to be found outside the ABM in the economic geography literature. Location factors may play an important role in determining the success of restructuring, with the most urbanised and most closely-linked regions exploiting the advantages of economic integration and therefore reducing the effect of restructuring on unemployment. This hypothesis 
has been long discussed in the transition literature (see e.g. Lehmann and Walsh, 1999; Newell, Pastore and Socha, 2002; Fazekas, 2000; Newell, 2005) and is considered in more detail in the following sections.

Before we proceed, some issues require brief discussion. First, it is perhaps interesting to note that our conclusion on the benchmark OST model's predictions regarding regional unemployment seems to be in line with those made by authoritative economists. In the early 1990s, Blanchard, Commander and Coricelli (1994) argued that unemployment in transition countries may be due to two main factors: (a) an increasing share of long-term unemployment generating low outflow from unemployment into jobs; (b) or a persistently high inflow from employment to unemployment.

Second, the ABM implies that the primary factor in (regional) unemployment in transition countries is industrial restructuring and the ensuing process of workers' reallocation from the state to the private sector. This factor is more influential than, as claimed instead by - among others - Dewatripont and Roland (1992), aggregate disturbances. This debate is reminiscent of that on Lilien's (1982) hypothesis that sectoral shifts drive aggregate unemployment. Abraham and Katz (1986) objected that it is hard to disentangle sectoral shifts from aggregate disturbances. Elhorst (2003, pp. 733-735) surveys the recent literature relative to mature market economies.

\subsection{The BM and its predictions}

The OST literature comprises further developments of the ABM. Two waves of theoretical models subsequent to the ABM can be distinguished. Blanchard and Kremer (1997) initiated the second wave by focusing on the specific forces driving the process of transformation in the CIS, a region beyond the scope of this paper. Boeri's (2000, Ch. 2) model (henceforth BM) marked the beginning of the third wave. In the terms of the two hypotheses defined in the previous section, the BM dwells upon the assumption about the constant hiring and separation rates (hypothesis $H_{1}$ ), while also putting forward arguments related to labour supply rigidities as factors liable to hinder adjustment to the equalisation of unemployment differentials.

Boeri (2000) points out what he perceives as the main shortcoming of the ABM: its overly simplistic assumptions concerning the way in which the labour market works. Only slightly more than $10 \%$ of the labour market transitions in Poland during the early 1990s would be accounted for by the benchmark OST model, which would neglect two important facts in particular: (a) the high flow to inactivity; (b) state-to-private and private-to-state sector transitions. However, these two factors explain the most distinctive features of transitional 
labour markets: (a) the reduction in labour market participation, especially among the male population; (b) the reduction in employment. They both imply an inward shift in labour supply, which would explain, in turn, increasing unemployment rates.

Boeri attempts to assemble all the evidence just discussed in a model based on an aggregate matching function whose arguments are vacancies and job-seekers. The existence of various types of labour market transitions makes graphical representation difficult. For this reason, no attempt is made here to reproduce the structure of the BM.

The assumptions of the model are as follows (Boeri, 2000, p. 71). First, restructuring means not only downsizing but also changing the product specialisation of firms. There are two sectors in Boeri's model: an old sector and a new one, which are not to be confused with the state and the private sector, in that state firms could restructure and produce new goods. Second, unlike in the ABM, separations may be not only to unemployment, but also to employment in the new sector and to inactivity. Third, employers offering jobs in the new sector can recruit either from among the non-employed or from among workers employed in the old sector. Employed and non-employed workers have the same productivity, but employers are not indifferent between the two types of workers, as the non-employed have a higher reservation utility and hence are less likely to accept a job in the new sector owing to the availability of generous non-employment (unemployment and inactivity) benefits. As a consequence, once a worker has opted for non-employment, s/he finds it difficult to accept a job in the new sector.

The model is calibrated against real transition data, and different scenarios are presented on the basis of specific assumptions which essentially concern the evolution of the level of unemployment benefits over time. The results in Boeri (2000, p. 78) are presented in relation to two scenarios: one of low and one of high unemployment benefits at the outset of transition. The results of the model are the following: (i) the length of transition depends on the generosity of non-employment benefits at the outset of transition: low (high) non-employment benefits bring transition to an end in eight years (over ten years); (ii) the output fall observed at the outset of transition is the consequence of the large drop in employment in the old sector, which is not counterbalanced by equal growth in the new sector, because workers flow to inactivity; (iii) the only way to shorten the reform process and reduce the non-employment pool is to increase the fungibility of non-employed workers by reducing their reservation utility; (iv) however, a reduction in the non-employment benefit system is effective only when the nonemployment pool is very small: when the non-employment pool is large, reform of the benefit system is ineffective and non-employment becomes persistent. 
The main conclusions of the model are: (a) unemployment is persistent because the unemployed are crowded out by employed job-seekers; b) the initial stages of transition crucially determine the degree of persistence of transitional unemployment.

The novel features of this approach compared to the ABM are as follows. First, the benchmark OST model had wrong policy implications. Neglecting labour supply has meant that much emphasis has been placed on the issue of gradualism versus the big-bang approach to reforms. This emphasis was ill-placed, because it amounted to assuming that the government was able to control the pace of closure of state enterprises and to overcome the resistance of insiders to restructuring by 'buying them off' with generous non-employment benefits. However, if quits due to voluntary choices, rather than layoffs, are the main cause of job separations, the latter should be considered an endogenous variable. High unemployment benefits will tend to increase the flow to non-employment and reduce the flow to new jobs.

According to Boeri (2000, p. 43), the key policy variable during transition is unemployment benefit, but not in the sense with which the early transition models considered it. Boeri maintains that all transition countries made the wrong choice in regard to the timing of unemployment benefits. They made overgenerous non-employment benefits available from the outset, thereby creating the conditions for stagnant unemployment pools throughout transition: "Rather than starting with generous non-employment benefits and then subsequently cutting them down, our framework suggests that the right sequence should have been the other way around" (Boeri, 2000, p. 56).

In addition, the third strand in the OST literature has the merit of anticipating the problems of economic transition typical of the late 1990s and early 2000s, when the old sector has almost disappeared and the reform process is close to conclusion in CEE. Although still sizeable in some countries in the late 1990s, such as Poland (World Bank, 2001), the leftward shift of labour demand experienced in the immediate aftermath of economic transition as a consequence of heavy industrial restructuring, has with the passage of time become as important as the ability of labour supply to adjust to it. The BM is thus a bridge between the OST literature and the neoclassical explanation of regional unemployment differentials in terms of frictions which impede the adjustment process, as discussed in Section One.

\section{Testing the OST assumptions and predictions about regional unemployment}

\subsection{The hypotheses}


The following predictions of the OST theoretical literature have been subjected to applied analysis:

a) Hypothesis $H_{1}$ against $H_{0}$;

b) If $H_{0}$ holds true, one should also find a close correlation between the degree of industrial restructuring, on the one hand, and the amount of labour turnover and regional unemployment on the other. The argument is that put forward in Lilien (1982). Sectoral shifts that do not simultaneously alter the aggregate level of the demand for labour will have no impact on unemployment only if workers are perfectly mobile and substitutable. However, if workers are not perfectly mobile and substitutable, shifts in the sectoral composition of labour demand will have an impact on the local unemployment rate. Vice versa, if $H_{1}$ holds true, there should be no correlation among the degree of industrial restructuring, the amount of labour turnover, and the unemployment rate. Figure 5 gives a graphical representation of $H_{1}$ versus $H_{0}$.

As noted in Newell, Pastore and Socha (2002), where unemployment depends on a high degree of industrial restructuring and job separation, one should observe a considerable difference in labour turnover across regions with different unemployment rates. In contrast, where unemployment depends on low job finding and therefore on a large share of long-term unemployment, one should observe no difference in labour turnover across regions with different unemployment rates. This "empirical law" appears to be one of the most interesting results of the debate on regional unemployment in transition countries, and it could also be fruitfully applied to regional unemployment in other countries.

Figure 5. Restructuring, workers' reallocation and unemployment

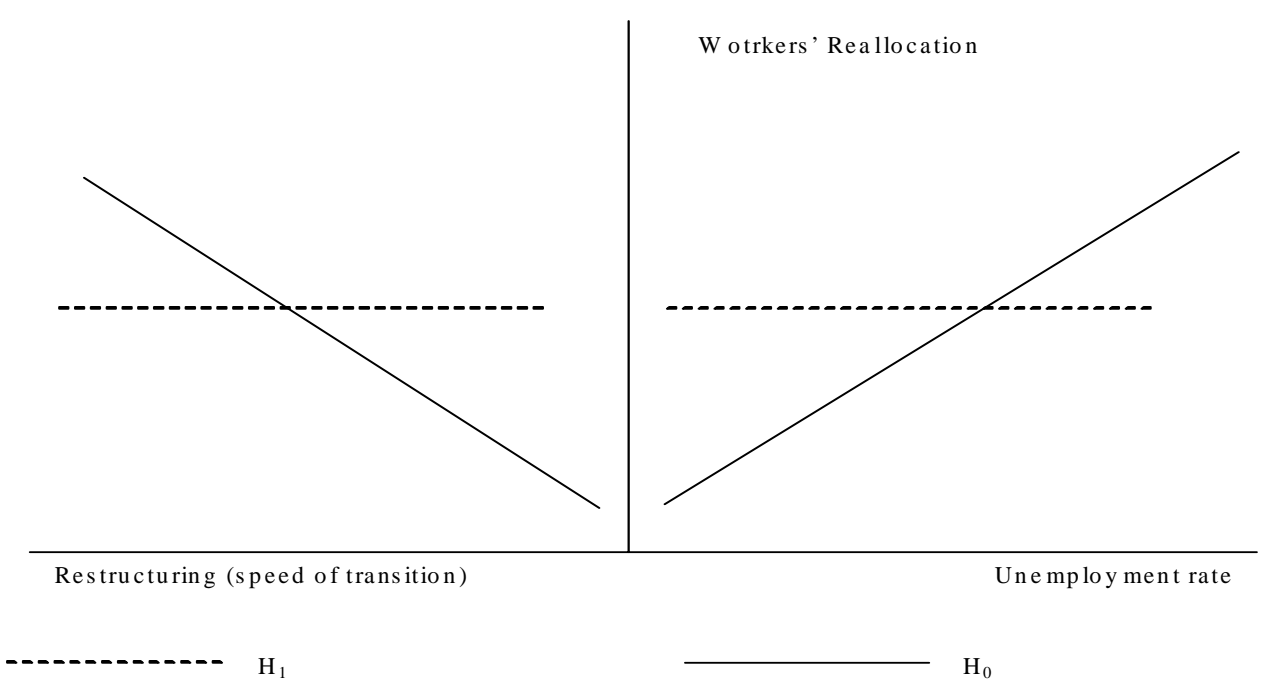


Relating to point $b$ ) is the issue of finding an indicator of industrial restructuring which is independent of aggregate negative shocks and exogenous with respect to labour turnover;

c) if $H_{0}$ holds true, one would expect high (low) unemployment regions to be more (less) developed and close to (far from) successful completion of the reform process. This conclusion has sometimes been used to justify the claim that the unemployment rate is the best indicator of the speed of restructuring and transition. An alternative possibility is that some developed regions have a low unemployment rate thanks to their ability to integrate with the world economy and reduce job losses;

d) several studies have estimated the determinants of job separations and/or job finding at a regional level;

e) according to the hypothesis $H_{1}$, and the neoclassical tradition, regional unemployment persistence during transition is related to several labour supply constraints;

The rest of this section surveys the empirical literature on the above issues.

\subsection{Testing $\mathrm{H}_{1}$}

The next step in the analysis - point (a) in section 4.1 - is to consider the results of applied research which tests $H_{1}$ against $H_{0}$. This involves inspection of labour market dynamics across regions. The focus has been on the distribution of gross and net job flows based on firm level data (see e.g. Faggio and Konings, 2003; Walsh, 2003) as well as on gross and net worker flows based on individual level data (see e.g. Cazes and Scarpetta, 1998; Newell and Pastore, 1999; 2000; Boeri, 2000; Cazes and Nesporova, 2001; World Bank, 2001). The conclusions reached in this literature are somewhat ambiguous, because they reflect differences in the data source used.

As already noted previously, Boeri and Scarpetta (1996) and Boeri (2000) are the best examples of advocates of hypothesis $H_{1}$. Boeri and Scarpetta (1996, p. 253) find evidence of slowdown of industrial restructuring in high unemployment regions already in the early 1990s. The stabilisation of unemployment differentials occurred therefore at the cost of increasing differences in non-employment rates across regions. Finally, wage moderation and labour mobility offered a limited contribution to the reduction of labour market imbalances.

Boeri and Scarpetta (1996, p. 239) build a classification of regions in five CEECs (Bulgaria, the Czech Republic, Hungary, Poland and the Slovak Republic), based on their structural characteristics. The taxonomy uses a sequential selection process. In the first step, three broad groups were identified, namely regions with a marked specialisation in agriculture, those dominated by industrial activities and a residual group of more diversified regions. In the second step, each of these three groups was split into more developed and less developed 
regions on the basis of various structural indicators. Interestingly, they also find a low degree of labour turnover in low unemployment regions - with a developed diversified economic structure - in all the countries considered, except for the Czech Republic, and argue that it was achieved through sizeable direct job-to-job shifts, with relatively less intermediate unemployment spells. Labour turnover was measured as monthly inflow and outflow from unemployment as obtained by unemployment register data.

Boeri (2000, Ch. 3) argues that long-term unemployment and the low degree of mobility of unemployed workers from rural to urban areas are important factors in explaining also the regional unemployment distribution in Poland. He finds evidence that: (a) the distribution of the reservation wage by levels of education is much flatter in rural areas, suggesting that highly educated workers expect a very low wage premium in those areas; and (b) it is higher for loweducated workers in rural rather than in urban areas, suggesting that low-skilled workers are better off in rural areas. They prefer to be involved in home production or family-run businesses, often in the informal sector, rather than move or commute to urban areas. For the same reasons, in rural areas the low-skilled unemployed tend to flow to non-participation, rather than to unemployment, as is instead the case in urban areas.

Newell and Pastore (2000) have compared average transitions from employment to unemployment, and vice versa, with regional unemployment rates, in 49 Polish voivodships ${ }^{13}$ during the period 1994-1997, which was before the reform that reduced the number of administrative units to 16 . They use labour force survey data to compute annual gross worker flows and find a correlation coefficient between the job separation rate and the unemployment rate of 0.76 , significant at the one-percent level. Not surprisingly, also the job finding rate displays a similar degree of correlation to the unemployment rate. Overall, high unemployment voivodships tend to be regions of large-scale transitions from employment to unemployment. Hence, high unemployment is related to high rates of destruction of job-worker matches and low unemployment is related to greater job stability, which seems to contradict the received wisdom according to which the greater the degree of flexibility in local labour markets, the lower the level of unemployment. This is as one would expect if industrial turbulence is a major cause of the regional pattern of unemployment and suggests that higher rates of separations derive from the higher-than-average speeds of transition of some regions.

This finding seems only partly confirmed, however, by gross job flows computed on the Amadeus data base and covering large-sized firms (more than 100 employees), mainly in the manufacturing sector. Plotting gross job flows over the period 1994-'97 as reported in Faggio and Konings (2003, Tab. 5) against voivodship unemployment rates in 1994 and in 1997 gives invariably a flat line, supporting the hypothesis $H_{1}$. The difference from previous studies may be 
attributed to the different nature of the data: restructuring at the level of large-sized state-owned enterprises might not represent well the overall level of labour turnover, which is decisively affected also by the documented difficulty to survive of newly established small-sized private enterprises.

Lehmann and Walsh (1999) support hypothesis $H_{0}$ by attributing a decisive role to the human capital level of the population inherited from the past. They develop a theoretical model similar to the ABM, but where separations are endogenously determined by the quality level of human capital in the region. Where human capital is fungible, workers do not oppose restructuring, which takes place generating unemployment, but also fast output recovery. Like in the $\mathrm{ABM}$, unemployment benefits play an important role, that of a temporary pit-stop in the reallocation process. The authors build a classification of Polish regions by level of economic development and find that the low unemployment regions are those regions where the restructuring process was very slow. These include the regions on the Eastern border, where the economic structure is less diversified and human capital is hard to adapt to the needs of the market economy.

Walsh (2003) develops the work by Gòra and Lehmann (1995) and Lehmann and Walsh (1999). He builds a classification of Polish regions by the level of inherited public infrastructure, as measured by the number of telephone, of fax machines, of railways, of public roads, of employment in services and of urbanisation. He ends up with six groups of regions and finds a non-linear relationship between the degree of job reallocation (as measured again with firm level data drawn from the Amadeus data base) and the average local unemployment rates in these groups of regions: low local unemployment is achieved either via high unemployment inflows with short unemployment spells or with low inflows with long durations (Walsh, 2003, Tab. 1). The former group of regions includes some of the most developed voivodships and the latter some of the least developed regions on the Eastern border with Belarus. Walsh (2003) concludes that the $\mathrm{ABM}$ is right in considering unemployment benefits useful to speed up the process of reallocation and that job-to-job moves had not the important impact on local unemployment rates as assumed in the BM.

In fact, the conclusions of Walsh (2003) are not in contrast with those of Newell and Pastore (2000). Also the latter find that low unemployment rates are either in very developed (Western and urbanised) or in depressed (Eastern) regions in Poland. However, labour turnover, as measured using individual level data, is found to be lower than average also in booming regions. 


\subsection{An empirical law about regional unemployment?}

The aim of this section - point (b) in section 4.1 - is to survey the attempts to test for the causality chain from industrial restructuring to workers' reallocation to unemployment hypothesised in Figure 5. As already noted, this exercise requires one to find an exogenous measure of the degree of industrial restructuring, which is independent of aggregate shocks. Newell and Pastore (2000) propose the index of industrial turbulence suggested in Layard et al. (1991, Ch. 6). This measures the fraction of all jobs in the economy that have changed sector of industry. ${ }^{14}$ The authors calculated this index for Poland using the May 1994 and November 1997 Labour Force Surveys, these being the earliest and latest available surveys using a consistent 32-industry classification. ${ }^{15}$ Similar indices for other dimensions of the transition were also calculated: by ownership in order to capture privatisation, and by firm size. The percentage figures are sizeable. The share of workers changing their sector of industry was $19.6 \%$ in low unemployment regions and $25.1 \%$ in high ones ${ }^{16}$.

Moreover, the authors present the correlations across voivodships between these restructuring indices and unemployment rates. They find a strong correlation between industrial change and change in ownership, on the one hand, and unemployment rates on the other. Moreover, inflow rates and industrial change are strongly correlated. Lastly, unemployment and outflow rates are significantly correlated, although outflow rates are uncorrelated with inflow rates and industrial change.

The correlation with the degree of restructuring by firm size is much lower, owing to the small number of cases considered: the Polish labour force survey includes only five classes of firm's size. However, as also noted by Blanchard (1994) and Barbone et al. (2000), it is likely that most changes have occurred within, rather than among, the size groups considered.

Krajnyàk and Sommer (2004) find a strong correlation between the same index of industrial turbulence used by Newell and Pastore (2000) and the unemployment rate at a regional level in the Czech Republic over the years 1998-1999, when restructuring actually started.

While attempting to test the hypotheses and predictions of the OST theoretical literature, the empirical literature also tried to assess the role of cyclical or aggregate demand-driven factors, compared to structural determinants in the restructuring of Polish manufacturing, especially during the early stages of transition. The results are ambiguous. On the one hand, Borenztein and Ostry (1992) and Borenzstein et al. (1993) argue that no significant structural change had taken place and that most of the decline in output is due to purely aggregate components. On the other hand, Barbone et al. (1999) find evidence in favour of the opposite 
thesis, uttered first by Berg (1994), using a new data set including a detailed industry classification. They decompose the labour productivity growth of various two-digit sectors of industry, finding that structural determinants of the recovery outweighed cyclical ones. This would suggest that restructuring, rather than the output fall was responsible for the relevant loss of jobs the country experienced in the early 1990s.

This research confirms the impression that a continuous structural change and the ensuing destruction of jobs are the forces driving regional unemployment during the first decade of transition. The transition process has not happened in one single year, but over a long period of time and is in many CEECs still in place. Moreover, there is evidence that structural change and job destruction are dispersed unevenly across regions, and dispersed in a persistent fashion. The aim of the following sections is to understand why this was the case. Different demand and supply side factors are considered.

\subsection{Demand side factors}

This section deals with the sources of structural change and the relationship between fast restructuring and unemployment - point (c) and (d) in section 4.1.

A. The initial conditions. The communist legacy is not a constant across regions. Historical differences affect the development of regions in various ways. First, important differences existed in the model of socialism adopted in each country: in Yugoslavia cooperative enterprises operated in a quasi-market environment, while in Poland, for instance, agriculture was never entirely collectivised. Only in Northern Poland was state agriculture common, and this, according to many authors, explains the high local rate of unemployment in the 1990s. Some countries, such as Hungary and the Czech Republic, started the reform process already in the 1980s, though blandly.

Second, in the absence of market mechanisms, the communist planner sought to define artificial models of product specialisation, allocating to some regions the task of producing only certain goods for the entire country. Regional development was conceived as forced industrialisation and consisted of locating large plants in remote rural areas. The one-industry town was also a typical outcome, with some towns being developed around one individual manufacture employing almost all the inhabitants.

Amongst others, OECD (1995) assumes that transition hit hardest the regions in which the former socialist planner had concentrated the largest part of manufacturing. The abolition of the state subsidisation system and increasing internal and external market competition pushed those 
activities out of market, generating unemployment. The argument is reminiscent of that of Lilien (1982), mentioned previously.

Linked to Lilien's argument, is that of Simon (1988) and Simon and Nardinelli (1992). They found evidence of a portfolio effect in the US labour market using the Herfindahl index to measure the degree of industry concentration in estimates of the determinants of Sates unemployment. The hypothesis is that the higher is the degree of industry diversification, the lower is the impact on the local production structure of a sectoral shift and the higher is the probability for dismissed workers to find employment in other sectors. ${ }^{17}$

In the case of Poland, several authors (see e.g. OECD, 1995; Gorzelak, 1996; Rutkowski and Przybila, 2002; Pastore, 2004) have noted that all the least diversified regions were hit by high unemployment rates. These include the northern regions (dominated by large state-owned farms), Gdanskie (by the steel industry), Lódzskie (by the textiles and clothing industry), and Walbrzyskie (by coal mining). Using micro-data drawn from labour force surveys, Cazes and Scarpetta (1998) find evidence of localised unemployment effects of past industrialisation policy in some regions of Bulgaria and Poland. Fazekas (2002; and 2003) supports this view for some Hungarian regions.

Conversely, other regions had more diversified production structures, so that they were able to minimise the risk of aggregate shocks. This was especially the case of the most urbanised areas, such as, in the case of Poland, Warszawskie, Bielskie, Katowickie, Krakovskie, Poznanskie, Skiemewickie.

However, whether the degree of industry diversification inherited from the communist era had an impact overall in the country is difficult to prove. Gòra and Lehmann (1995), Scarpetta (1995) and Scarpetta and Huber (1995) used micro-data and tested whether the probability of job finding, estimated either by multinomial logit or survival analysis, was affected by the level of development, measured by means of several classifications of regions, and by the degree of industrial diversification, proxied by indices of industrial concentration (the Herfindahl index). They were unable to find clear evidence for an impact of economic development. Scarpetta (1995) found a statistically significant positive impact of the Herfindahl index on unemployment in the case of Hungary. A similar conclusion was reached by Lehmann and Walsh (1998). Boeri and Scarpetta (1996) notice that there is no correlation between unemployment rates and the economic structure of the regions in five CEECs in the early 1990s.

Newell and Pastore (2000) argued that the classifications used in previous studies tended to consider the level of development, rather than the pace of economic development, and the degree of restructuring. Also Newell, Pastore and Socha (2002) did not find econometric evidence for such a correlation using and the same classifications of regions and the same index 
of industrial concentration in a later period (1994-'97). They analysed labour force survey data relative to Poland and estimated the probability of job separation (rather than of job finding) by means of survival analysis.

Using aggregate cross-regional data and multiple regression analysis, Rutkowski and Przybila (2002) instead found a positive ceteris paribus relation between the hiring rate of a Polish voivodship and the share of services, taken as a measure of the degree of industry diversification. They argue that the independent contribution of variables related to economic growth is limited, because they are correlated with variables representing the economic structure of the region. In turn, these last explain about $80 \%$ of the variation in job finding rates.

A further test consists of verifying whether there is a systematic correlation between the average firm size, taken as a measure of forced industrialisation from the past communist system, and the local unemployment rate. Scarpetta (1995) found a negative sign in the case of Hungary and Poland, but a positive one in the case of the Czech Republic. Herzog (2000) develops the work of Scarpetta (1995), but focuses on regional employment change. He concludes that concerns regarding plant scale and industry agglomeration are unfounded in the case of Poland and the Slovak Republic in the early 1990s.

Third, some countries and regions are closer than others to the core of Europe. In almost all CEECs, the capital city, the most urbanised regions and those close to the Western border have lower unemployment rates, while unemployment concentrates in rural areas on the Eastern border, with the exception of the Eastern regions of Poland, where the reform process has progressed very slowly and so has also unemployment (Gorzelak, 1996; Fazekas, 2002, p. 178). The ability to attract direct and indirect capital flow depended not only on geographical proximity to Western countries but also on other factors, such as ease of market access (presence of good transportation systems at low cost), the size of local markets (as measured, for instance, by per capita GDP), and so forth. The role of distance and its impact on economic integration will be considered in more detail in the last section of this paper.

The problem with the initial conditions and the communist legacy is that, as a multifaceted fact, it did not always affect unemployment in the same way, so that it is difficult to assess its overall impact.

B. Technological upgrading. Economic transition and the opening up of the economy imply a process of technological upgrading, also fostered by investment from abroad. This is a specific factor of economic change, sometimes defined "defensive restructuring”, which in itself is able to affect unemployment differentials via shifts in labour demand away from low-skilled and towards high-skill labourers. Technological upgrading may favour the more developed 
regions endowed with a higher level of human capital, on the one hand. On the other hand, a high concentration of human capital in some regions may trigger economic growth and employment, while reducing the average risk of long-term unemployment, since high-skill workers are more mobile and fungible. In addition, a high concentration of human capital in the local labour market may favour further technological upgrading, thus generating a cumulative processes.

Rutkowski and Przybila (2002) find a positive correlation between the voivodship’s hiring rate and the share of workers with secondary or higher educations. They also show that a higher level of development, a more diversified economic structure, better infrastructures, especially related to communication, flexible wages also correlate with higher than average regional hiring rates. A similar conclusion, again for Poland, is reached in Newell (2005).

In turn, this is evidence in favour of agglomeration factors. In other words, job opportunities tend to concentrate in urbanised, "central” regions, as one would expect if returns to scale and social externalities of human capital and technology were at work.

\subsection{Supply side factors}

The following supply side rigidities mentioned under point e) in section 4.1 are considered here: (i) insufficient wage differentials; (ii) the insufficient sensitivity of wages to local labour market conditions (wage curve hypothesis); (iii) low interregional labour mobility; (iv) the minimum wage. The role of unemployment benefits has already been discussed in previous sections.

(i) Insufficient wage differentials. As noted in section two, low wage differentials and insufficient labour mobility may be factors able to generate the persistence of regional unemployment. Conversely, sufficiently large wage differentials may help absorbing negative shocks. In fact, if wages reflect adequately local unemployment rates, then depressed, high unemployment regions may be favoured if the unemployed move towards low unemployment, but high wage regions and if capital moves in high unemployment regions, attracted by the low cost of labour. The consequence will be the equalisation of unemployment differentials. This type of adjustment mechanism seems to work in a different way in the USA and in the EU, producing different outcomes in terms of employment and inactivity rates. In the USA, as Blanchard and Katz (1992) find, the speed at which labour moves out of high unemployment regions is much higher than that at which capital moves in. The consequence is that employment and output levels will be permanently lower in depressed regions. In the EU, as 
Decressin and Fatàs (1995) find, regional unemployment rates also tend to converge, but at the cost of reducing activity rates in high unemployment areas, rather than employment, since workers are scarcely mobile.

OECD (1995) was the first study to point out the role of insufficient wage differentials (and low labour mobility) as possible determinants of regional unemployment persistence in CEECs. Various sources of wage rigidity were considered. Several countries implemented tight wage policies already in the early 1990s to curb two- or even three-digit inflation. Wage policy is a potential source of wage rigidity if wages are fixed at a national level, without considering spatial differences in productivity growth. The fear that wages were becoming rigid caused, in turn, the withdrawal of wage policies in most transition countries already in the second half of the 1990s. Moreover, the wedge between the cost of labour and the net wage actually earned by workers is higher than in other EU countries, also because of the burden unemployment benefits represent for the State budget. ${ }^{18}$

Despite these potential sources of wage rigidity, according to Bornhorst and Commander (2004), wages in transition countries are not inflexible, just the contrary. In fact, regions that have experienced larger adverse shocks have been characterised by lower relative rates of wage increase, but also by lower employment increase. Their conclusion is that wages do depend on local labour market conditions, but the actual degree of wage flexibility is insufficient to absorb negative shocks. Fazekas (2000) reaches a similar conclusion looking at the Hungarian case.

Rutkowski and Przybila (2002), instead, find a positive correlation between the job finding rate and the degree of wage flexibility across Polish regions. Wages are considered flexible when the productivity is higher relative to wages and the wage structure is less compressed. Landesmann (2002), however, notes that causality might go the other way around, since booming regions might have higher productivity growth and wage dispersion is higher in areas with a more diversified production structure. Sibley and Walsh (2002) find in fact that in Poland wage dispersion is higher in regions that experience a higher degree of restructuring, are more advanced and open to international trade.

(ii) Sensitivity of wages to local labour market conditions (the wage curve hypothesis). One way to measure the degree of flexibility and efficient functioning of the labour market is by estimating the sensitivity of wages to local labour market conditions. Blanchflower and Oswald (1994) suggested the so-called wage curve to ascertain whether wage differentials follow any unemployment pattern. It consists of testing for statistical significance the coefficient of regional unemployment rates (in natural logarithm) in Mincerian-types of earnings equations. The expected sign is negative. The main idea behind the wage curve is that wages should react to increased unemployment at a local level, after controlling for human capital levels and other determinants of individual earnings. Blanchflower and Oswald (1994) find a coefficient of around -0.1 , remarkably stable in the case of mature market economies. ${ }^{19}$ 
Blanchflower (2001) provides a short survey of the evidence relative to CEECs until 2001, which was still scarce, inconclusive and difficult to compare with that of mature market economies. He also estimates a wage curve for several CEE and CIS transition economies using different types of data sets and definitions of wages. The International Social Survey Programme data base relative to the period 1991-'97 suggests a wide variation of coefficients: several countries (the Czech Republic, Hungary, the Slovak Republic) have a wage curve effect lower; the GDR has a coefficient similar; and other countries showed coefficients generally much higher than that found previously. The unemployment elasticity of pay ranged from -0.15 for Poland, to -0.24 for Bulgaria and -0.46 for Latvia. They imply that doubling the local unemployment rate causes a wage reduction by $15 \%$ in Poland, by $24 \%$ in Bulgaria and by $46 \%$ in Latvia. No wage curve effect is found for Slovenia, confirming the results of other studies on the high degree of labour market rigidity in this country.

Blanchflower (2001, Table 7) presents similar estimates carried out on World Bank HEIDE data base relative to the period 1993-'95. They form a different picture: all CEECs in the sample exhibit a high wage curve effect, including Hungary $(-0.36)$ and Slovakia $(-0.19)$.

Duffy and Walsh (2000, and 2001) provide an interesting addition to the traditional wage curve hypothesis. The equation, estimated in a panel data framework to control for omitted variables bias, has voivodship wages relative to the period 1991-'96 as dependent variable and a ranking of regions according to the degree of restructuring in addition to the regional unemployment rate as regressors. Both variables are significant at the $5 \%$ level. They find a wage curve effect of -0.12 and argue that wages mirror also the degree of restructuring, since as predicted in the $\mathrm{ABM}$, workers accept restructuring only provided that they receive higher wages in the new jobs. The restructuring elasticity of pay is estimated to be 0.07 .

Iara and Traistaru (2004) study the degree of wage flexibility for four transition countries (Bulgaria, Hungary, Poland and Romania) over the period 1991-'99. Average real regional earnings are the dependent variable. Iara and Traistaru (2004) provide static panel estimates (Least Square Dummy Variables) for comparative purposes, GMM estimates based on the Arellano and Bond methodology to control for endogeneity of the unemployment rate and estimates based on spatial filtering to control for spatial dependence. The LSDV estimates yield wage curve effects only for Bulgaria $(-0.05)$ and Poland $(-0.06)$, but insignificant coefficients for Hungary and Romania. The GMM estimates confirm the results of previous estimates for Hungary and Romania, but generate different coefficients for Bulgaria $(-0.12)$ and Poland (0.04). Spatial filtering confirms previous results for Bulgaria, Poland and Romania, but suggests that in Hungary wages respond to local unemployment with two years of delay, though this effect disappears in the long run. 
Svejnar (2002b, p. 14) reports that attempts to find evidence of a wage curve in several transition countries based on firms' level data failed.

To sum up, the research efforts on the wage curve have led to mixed evidence: (a) contrary to what previously found for mature market economies, different data sources produce different results; (b) nonetheless, the available evidence suggests that "The unemployed serve to bid down the wages of those in work in both East and West and to an approximately similar degree" (Blanchflower, 2001, p. 15); (c) and, finally, in some transition countries wage flexibility seems to be much higher, than in others (especially Slovenia and Romania).

(iii) Interregional labour mobility. Another mechanism through which geographical differences in unemployment rate can be absorbed is interregional labour mobility. Blanchard and Katz (1992) find that labour mobility, more than any other factor, including capital mobility, is decisive in achieving regional convergence in unemployment rates across the United States. They also find that labour mobility is driven more by the need to escape from unemployment in depressed areas than by the attraction of higher wages in booming regions.

Already in the early 1990s, OECD (1995) noted that despite being neither abundant nor fully reliable, the available information on labour mobility concurrently pointed to very low interregional flows, which further declined during transition. ${ }^{20}$ Bornhorst and Commander (2004, Tab. 7 and Fig. 4) show that, though reacting to economic incentives, internal migration flows remained persistently low in several transition countries, throughout the 1990s. Gross migration rates are similar to those typical of low mobility EU countries, such as Spain and Italy. As a consequence, net migration flows are positive in low unemployment regions, as one would expect, but such a correlation is weak, sometimes statistically insignificant. This flow is considered insufficient to compensate large unemployment differentials. Similar conclusions are reached by Rutkowski and Przybila (2002) for Poland, and by Kertesi (2000) for Hungary.

Fidrmuc (2004) considers the case of several transition economies, adding that gross migration, both inbound and outbound, is more sizeable in developed than in peripheral regions, suggesting that migration might contribute to increasing regional differentials, by pooling high skill workers in developed regions and separating them from depressed regions.

The debate has also addressed the issue of the factors hindering internal migration. The research on the wage curve surveyed in the previous section suggests that wages do respond to local labour market conditions. What is, then, the reason of the low interregional mobility? Already in the early 1990s, the high cost of housing and a poorly functioning rentals market were decisive. These were, in turn, the consequence of various factors, such as the dominance of owner-occupying housing, the lack of clarity over property rights and the absence of long-term housing finance. Nonetheless, no systematic analysis of these factors is available in the literature. 
In addition, as noted previously, Boeri (2000) and Rutkowski and Przybila (2002, p. 159) ascribe low labour mobility also to differences in reservation wages by skill and mismatch between the unskilled workers residing in high unemployment regions and the demand for skilled work in low unemployment areas. In rural areas, the low-skilled unemployed tend to flow to non-participation, rather than to unemployment, as it happens instead in urban areas. ${ }^{21}$ This argument would explain also Bornhorst and Commander (2004, Tab. 2) finding that regions with high unemployment have high non participation rates in 2000, with the only exception of Romania. These studies (see also Huber, 2004) suggest that low participation rates might be the way by which transition countries will absorb negative shocks in the long-run, like in the EU case depicted in Decressin and Fatàs (1995).

(iv) The minimum wage. The aim of research in this field has been to show that a nationwide arrangement like the minimum wage - common in almost all CEECs - may produce different effects across regions. As well as increasing the overall degree of wage rigidity, thus hindering labour mobility, the introduction of minimum wage arrangements may cause low job creation for the low-skill unemployed especially in high unemployment regions. In fact, the minimum wage represents an important share of the wage of low-skill workers there and thus dramatically reduces their likelihood of finding jobs by truncating the earnings distribution (Rutkowski and Przybila, 2002; Kertesi and Köllo, 2003).

In the case of Poland, Rutkowski and Przybila (2002, pp. 166-9) note that the minimum wage is set around $40 \%$ of the average (mean) wage. However, its "bite" (real effect) depends on the ratio to the average wage of low-skill workers in each region. An important step of the analysis is to contrast the minimum wage with the wages in different quantiles of the wage distribution. The result is that the bite is 48 percent for a median worker, but 65 percent for young workers, 72 percent for workers in elementary occupations, and as much as 82 percent for bottom-quintile workers. These figures suggest that the minimum wage truncates the wage distribution for less productive workers and is thus likely to exclude them from employment. The situation worsens when one looks at the bite of the minimum wage in the depressed regions, such as Slupskie, Wloclawskie and Ciechanowskie, where the minimum wage represents over $90 \%$ of the median wage for bottom-quintile workers. The authors corroborate this indication with econometric analysis, regressing the regional unemployment rate on the bite of the minimum wage (the ratio of the minimum wage to the region's bottom decile wage) and a set of other variables representing the region's level of development (per capita GDP, investment, level of human capital, employment structure, and infrastructure). They find a positive coefficient, at the $10 \%$ significance level when all the variables are included, and at the 
$1 \%$ level when per capita GDP, investment and the proxy for the level of infrastructure are dropped. These results suggest that a $10 \%$ nationwide increase in the minimum wage would result in a 3.1\% increase in the unemployment rate of depressed regions, other things held constant. Nonetheless, Rutkowski and Przybila warn that this pattern, found using cross-section analysis, may not hold in a dynamic framework. Besides the problem of causality, this type of estimate may suffer from omitted variable bias and multicollinearity.

Summary remarks on supply side factors. Overall, the literature surveyed in this section suggests that wage flexibility is not high, but not lower than in EU countries. More important is the low degree of labour mobility. But this in turn seems to depend on the rigidity of other markets, such as the housing market, and the weakness of the transportation infrastructure. Svejnar (2002b) points also to the rigidity of capital markets, of corporate governance regulations and of the business environment as factors no less important than labour market rigidity in fostering job creation and labour mobility.

\section{The role of economic integration and convergence}

Two types of low unemployment regions have been detected in previous sections. Few backward peripheral regions have attained low labour reallocation and, therefore, low unemployment by postponing the transformation. Other more developed and central regions have managed to attain fast restructuring with low labour turnover and greater job stability, because they have been able to attract sizeable flows of foreign direct investment and exploit the advantages of specialisation following the opening up of the economy. In the least successful regions, the cost of restructuring may have been particularly high, since fast restructuring was coupled with a backward economic structure and a substantial inability to exploit the advantages of economic integration. This section aims to discuss in more detail the role of economic integration with the world economy in shaping this pattern of unemployment in the new EU regions.

\subsection{The theoretical predictions on regional convergence in CEE}

This section discusses two opposing scenarios of the future economic geography of the recently enlarged EU. According to the first scenario, there will be a predominance of horizontal intra-industry trade, resulting in weak specialisation in terms of production and employment. By 
'horizontal intra-industry trade' (HIIT) we mean two-way trade in goods and commodities classified within the same industrial sector and of the same quality level. According to the traditional models of HIIT (Krugman, 1980; Helpman, 1981; Helpman and Krugman, 1985), this kind of competition typically arises among advanced countries with similar specialisation and factor intensities and generates the reciprocal rationalisation of productions, scale economies, more variety, and lower costs.

If this scenario of integration comes about, as argued in Frankel and Rose (1998), support will be provided for an optimistic view. The labour adjustment costs generally associated with horizontal intra-industry specialisation, in fact, are much less disruptive than those arising from inter-industry trade (IT), from vertical intra-industry trade (VIIT), and from outward processing trade (OPT). By 'inter-industry trade' is meant a kind of trade in goods and commodities classified in different industrial sectors and based on factor endowment differentials, whereas still meant by 'vertical intra-industry trade' is a two-way trade in goods and commodities classified within the same industrial sector, but of different quality level. "Outward processing trade” involves the exchange of raw materials and intermediate products against final products within the same broad industrial classification, and it is linked to the relocation of the production phases of firms from more advanced economies in less advanced ones.

The most common argument is that, since in the former case - HIT - factor input ratios in export and import sectors exhibit greater similarity than they do in the latter - IT, VIIT and OPT - the factor price differential should be narrower in the first case and, as a result, the adjustment to trade opening should be less dramatic in terms of factor prices and also in terms of employment. The reason for this would be that if factor intensities between sectors are similar, we should expect labour to transfer from one sector to another with relative ease. In fact, the skills acquired by working in the import substitute sector can be redeployed in the export sector with minimal retraining costs.

A less optimistic scenario of integration envisages increased specialisation based on comparative advantages and trade of inter-industry or of vertical intra-industry type. This latter has been explained by the so-called neo-Heckscher-Ohlin literature (Falvey, 1981; Falvey and Kierzkowski, 1987), which shows how IIT may result from a quality competition and is not necessarily associated with identical endowments and technologies. The adjustment effects of VIIT in terms of wage and employment are as dramatic as they are in the traditional H-O type of IT. Moreover, in all these cases, the risk of asymmetric shocks and of falling into development traps would be greater, because new EU members would develop trade relations based on their specialisation in traditional and unskilled labour intensive industries. As a consequence, they 
may remain locked in traditional sectors and reduce the opportunity to upgrade for a long period of time.

There are also important implications in terms of the spatial distribution of economic activities to consider. Under the hypotheses of the so-called New Economic Geography (NEG) literature, economic integration gives rise to a spatial core/periphery schema resulting in higher agglomeration which is especially detrimental to peripheral countries and regions. Dispersion and agglomeration forces depend on the interaction between imperfect competition, economies of scale and agglomeration externalities. Regional integration reduces transaction costs and encourages firms to concentrate so that they can benefit from economies of scale. Increasing return-intensive sectors will tend to concentrate in regions with good market access and better backward and forward linkages, while traditional activities with constant returns to scale will concentrate in peripheral regions. Moreover, the market size increases as manufacturing agglomerates and as cumulative causation occurs (underdevelopment traps). These models argue that closer integration would give rise to increased polarisation and specialisation. However, this relation is non-monotonic. Industrial agglomeration generates a regional wage differential. The immobility of the workforce cannot equal the regional remuneration, and wage competition becomes a centrifugal force. At low trade costs, firms become more sensitive to costs differentials, which induces the modern sector to spread into peripheral regions (Krugman and Venables, 1995; Venables, 1996; Puga, 1999).

Such models have considerable implications for the new EU regions. Further integration may increase the probability that industry spreads as a result of wage differentials among nations: Eastern European regions would attract low-skilled intensive activities, while the highskilled intensive activities would remain in the core.

\subsection{Contrasting theories and empirical evidence}

The different scenarios of integration outlined above have already been tested and contrasted in light of the integration of the old EU members during the past two decades. This research (see e.g. Fontagnè, Freudenberg and Peridy, 1998) has found that intra-European trade is mainly of intra-industry type, but of a vertical kind. Therefore, EU countries already face structural and technological asymmetries. However, polarisation is found to occur not so much across nations where production structures are roughly homogeneous as across regions, which are diverging within all European nations (Boldrin and Canova, 2001; and 2003). This is in line with the fact that labour is much more mobile across regions. This section reviews the main stylised facts on specialisation patterns and FDI dynamics in the new EU regions. 
Inter-industry trade. Inter-industry trade is a sizeable component of total EU15-CEE trade, ranging between 50 (Czech Republic) and 95\% (Baltic Republics) circa in 1996, and amounting on average to 55\% in 2000 (Caétano et al., 2002).

If one applies the Krugman index of relative specialisation to the old and new EU members (using sectoral export data for 72 products), we observe that the core and the largest countries are the least specialized; while the peripheral countries are more specialised than the EU average. Huge disparities exist among the new EU members. The Czech Republic, Hungary, Slovenia and Poland are more diversified than such peripheral countries as Portugal and Greece, while the Balkan and Baltic countries exhibit the highest values for the specialisation index (Dupuch et al., 2004).

New EU members are generally specialised in resource-intensive (metals, wood, and wood products) and labour-intensive (textiles and clothing) industries, while they continue to suffer comparative disadvantages in capital-intensive industries such as machinery, equipment goods, and chemical products (Freudenberg and Lemoine, 1999). However, there are wide divergences among these countries, and some of them are undergoing great changes in their trade specialisation. For instance, Hungary has achieved new specialisation in the electronic and computer industries, and Estonia in telecommunications (Caétano et al., 2002; Ferragina, 2004).

Intra-industry trade. As anticipated, existing IIT is not necessarily an indicator of similarity of trade between East and West Europe: as noted by Freudeberg and Lemoine (1999), the bulk of total IIT, between 80 and $90 \%$, is of vertical kind. This again demonstrates a certain specialisation by CEECs in low-value added segments. Vertical IIT has undergone significant decline in favour of horizontal IIT in the past decade only in those countries which initially exhibited higher levels of intra-industry trade.

The role of FDIs. Two distinct strategies regarding FDIs have emerged. Vertical multinational strategies predominate in the context of deeper inter-industry specialisation. Multinational firms locate the more labour-intensive stages of the production process, such as assembly, in countries with cheaper labour. Given that these FDIs are motivated by differences in factor endowment, the international division of labour that they support reinforces interindustry specialisation patterns.

In contrast, FDI is horizontal when multinational firms are attracted mainly by expansion on local markets. This type of FDI is more likely to occur between countries whose preferences are similar (Markusen, 1995). It depends on market access considerations and is more likely to 
come about in technology intensive industries, both increasing the number and improving the quality of products, and therefore reinforcing intra-industry trade patterns in goods of similar quality (Fontagnè et al., 1998).

Within new EU members, FDI is not evenly distributed by industrial sector, or by region. In 2002, three countries (the Czech Republic, Poland and Hungary) accounted for more than three-quarters of total FDI in the region (UNCTAD, 2003), while the Baltic Republics and Bulgaria accounted for less than $10 \%$.

In 1995, FDI appeared to be mainly directed to tertiary activities in the most advanced CEECs (the Czech Republic, Hungary and Slovenia), but more to manufacturing sectors and traditional activities in Poland and Romania (UNCTAD, 1997).

Eurostat (2002) data on stocks of FDI in 1999 confirms this picture. Three distinct patterns appear. The first pattern is typical of Bulgaria, with traditional sectors such as food and metals being the main beneficiaries. Poland, Slovenia, Slovakia, and the Czech Republic belong to the second group of countries, where FDI is more balanced across sectors. However, some countries still exhibit a large proportion of FDI in traditional sectors (food in Poland, metals in Slovakia), while the chemicals industry is the most attractive sector in Slovenia, and machinery and equipment goods receive the largest share in Slovakia. Finally, tertiary activities are dominant (two-thirds of the total stock of FDI) in the Baltic Republics (trade and distribution, financial activities, transport and telecommunications).

In Poland, 90\% of FDI was concentrated in Warsaw and a few other cities. Fazekas (2002; and 2003) provide evidence that also in Hungary most FDI was concentrated in Budapest and other urban regions. Nonetheless, a share of FDI in low-technology industries located also in some rural areas. Traistaru and Pauna (2002, p.15) report that over 50\% of the foreign capital flowing to Romania located in Bucharest.

To sum up, foreign investments in medium-high technology industries with high growth potential are already substantial. Since FDI favour the emergence of competitive firms, they also influence patterns of comparative advantage and therefore perform a key role in transforming the productive systems of some CEECs. However, this process is coming about unevenly across countries, and across regions within each country.

The role of human capital. The CEECs are rather homogeneous with the OECD average in terms of educational levels, except for Slovenia. However, according to Landesmann (2003), when the educational level of the active population alone is considered, around $30 \%$ of workers have not reached a secondary school level, and the share increases to more than $40 \%$ in the case of Bulgaria and Romania. Moreover, old EU members have a share of high-skilled workers 
(share of active population with a tertiary education level) amounting to around 20\%, whereas it is no more than $14 \%$ in the new EU members.

Finally R\&D expenditure is appreciably lower in the CEECs than the EU standard (1.93\% of GDP), which itself is not the highest in the world. In 2000, if we exclude Slovenia (1.52) and the Czech Republic (1.33), R\&D expenditure for the remaining CEECs ranged between 0.37 (Romania) and 0.7 (Poland) (Eurostat, 2002).

There is also evidence of the 'crowding out' of existing human capital by the process of economic transition, which helps explain the CEE specialisation in low-quality exports to EU markets (Greenaway and Torstensson, 2000; Ferragina and Pastore, 2005).

The evidence on trade and FDI trends suggests that the sectoral divergence resulting from agglomeration economies is likely to persist through a high skill core, attracting increasingly technology-intensive activities, and a low skill periphery. The Central European countries consisting of Slovenia, a few urban and border Hungarian and Polish regions, the Czech Republic and Slovakia - are likely to follow a 'Spanish model' based on catching up, industrial diversification and intra-industry trade, while the Eastern countries may lag further behind, increasing their comparative advantages in low-tech and labour-intensive sectors.

\subsection{Estimating the impact of economic integration on regional unemployment}

How the forces of economic integration affect the regional distribution of unemployment, in particular, is a neglected issue. A possible explanation of such negligence is brought to the fore by Suedekum (2003). He notes that New Economic Geography models assume full employment, while models aimed at explaining unemployment assume constant returns to scale and do not include international trade factors, leaving unexplained important features of the regional distribution of unemployment in the EU, such as the polarisation between a low unemployment developed core and a high unemployment depressed periphery. To explain this fact, he amends the wage curve by introducing increasing returns to scale and agglomeration factors. Whatever the solution found, it is clear, as claimed by Overman and Puga (2002) and Puga (2002), that international trade and inflow of capital from abroad tend to reinforce, not to weaken the existing pattern of unemployment.

Also the applied literature is still scarce, and the OST literature is no exception under this respect. One explanation of this is the methodological difficulty of the object under scrutiny, which would require a general equilibrium framework. As noted e.g. by Landesmann (2002), 
analysis of the labour market impact of economic integration requires careful consideration of the indirect effects on growth and economic performance. Focusing only on the direct impact in specific sectors would miss the point. In addition, suitable data at a regional level are still missing. This partly explains why the research efforts carried out so far provide only circumstantial evidence.

Fazekas (2000; and 2003) finds that in the case of Hungary a sizeable flow of FDI has concentrated in the most urbanised regions because of a strong concentration of a skilled work force. Moreover, capital inflow is negatively correlated with distance. An interesting finding is that rural regions on the Eastern border with Ukraine and the Slovak Republic attracted comparatively high levels of FDIs, other things held constant. This is attributed by Fazekas to the nature of the capital flow in different areas. Urban areas attract FDIs in skill-intensive industries, whereas rural areas attract capital flows in low-skill productions. These results confirm some of the aforementioned conclusions of Lehmann and Walsh (1999), Walsh (2003) and Newell (2005) regarding the role of human capital in shaping the pattern of regional unemployment in the new EU regions.

Fazekas (2000) also finds that despite the magnitude of the inflow of capital, its direct impact on local unemployment in Hungary is weak. This may be explained by the relatively high share of takeovers as opposed to "green-field" investment during transition, the relatively low labour intensity of foreign investments (compared to domestic enterprises), as well as the practice of hiring from the ranks of employed workers rather than from the pool of unemployed persons. Fazekas (2003) adds that FDI have contributed to reinforce the position of the urbanised regions on the Western border that were already successful in generating relatively more jobs out of domestic capital. She concludes that economic integration is expected to increase, not to reduce the spatial productivity gap.

Newell, Pastore and Socha (2002) furnish circumstantial evidence on how Poland's international comparative advantages in labour-intensive manufacturing combine with the economic advantages of urbanised regions to play a significant role in shaping the regional distribution of the country's unemployment. They estimate hazard functions of the probability of moving from employment to unemployment using individual level LFS data relative to the years 1994-'97 and find that the manufacturing sector, especially highly labour-intensive industries, provide their employees with particularly secure jobs in low unemployment regions, but not in high unemployment ones. They detect the factor intensity of industrial sectors applying the Neven (1995) taxonomy. They interpret their finding as reflecting a combination of comparative advantages in terms of factor intensities and agglomeration effects. A variable 
measuring the magnitude of capital flows at a vovodship level in the same econometric setting turns out insignificant, perhaps because of the high concentration in Warsaw.

A recent strand of literature is addressing the question why urbanised regions have been able to exploit the advantages of trade integration and of capital flow from abroad. The answer is that human capital concentration in urbanised regions is an important factor to attract FDI in advanced sectors and reduce the cost of restructuring. As already noted, this hypothesis is at the core of Lehamnn and Walsh (1999) and Walsh (2003) models. World Bank (2004, pp. 29-31) and Newell (2005) note a strong negative correlation between regional unemployment and the share of workers with a high level of education in Poland. In fact, individuals with a high level of human capital have shorter unemployment spells. Moreover, complementarity between high technology industries and human capital generate persistence in unemployment differentials with respect to rural, depressed areas. And this result may be reinforced by migration flows, as noted in Firdmuc (2004).

\section{Concluding remarks}

This paper has surveyed the explanations set out in the OST literature for the dramatic and persistent regional unemployment experienced in the new EU members after the beginning of economic transition. Two theoretical models have been considered: the Aghion and Blanchard (1994) model and the Boeri (2000) model. The former stresses the role of demand side factors, essentially the massive process of structural change experienced in all countries of Central and Eastern Europe, whereas the latter points to supply side factors, such as wage rigidity and labour immobility. Whilst the former seems better suited to explaining the onset of regional unemployment in the early 1990s and its persistence during the rest of the decade, the latter addresses the more recent argument that removal of various forms of labour market rigidities is an important condition for the adjustment process to reach completion.

The OST literature on regional unemployment has grown rapidly, reaching high levels of elaboration and providing a convincing explanation for the phenomenon under scrutiny. Moreover, it has made interesting contributions to the development of the general analysis of regional unemployment differentials. The most innovative contributions seem to be those which underline the relationship among industrial restructuring, labour turnover and spatial unemployment differentials. This relationship has hardly been studied previously in the case of mature market economies.

Many questions posed in the literature remain on the agenda. The main shortcoming of the literature considered seems to be its lack of a clear and unified theoretical framework. However, this conclusion amounts to saying that the literature on transition countries shares a problem 
typical of the general literature as well (see e.g. Elhorst, 2003). For applied economists, there are numerous topics still to be analysed. First, some studies should be updated to cover more recent years. Second, there are many areas in which analysis still seems to be incomplete, unsystematic and circumstantial. The availability of new data, especially of longer time series will probably help remedy this shortcoming in the near future.

Acknowledgements. We thank Vera Adamchik, Tito Boeri, Sergio Destefanis, J. Paul Elhorst, ByungYeong Kim, Hartmut Lehmann, Andrew Newell, Barry Reilly and Mark Schaffer for useful comments on earlier versions of this paper. The authors take responsibility for any errors that remain.

\section{Notes}

${ }^{1}$ For its specific transformation path, East Germany is beyond the scope of this paper.

2 OECD (1995) and Boeri and Scarpetta (1996) document the degree of persistence of regional unemployment in Bulgaria, the Czech Republic, Hungary and Poland during the years 1991-'95. Bornhost and Commander (2004, pp. 3-5) provide evidence relative to six transition countries (Bulgaria, the Czech Republic, Hungary, Poland, Romania and Russia) for the years 1991 and 2001. The focus of their analysis is mainly the NUTS3 level, though they also consider the NUTS2 level. Eurostat (2004a; and 2004b) covers the years 2002-'03. Evidence on specific aspects is provided for the Czech Republic, by Fidrmuc and Huber (2003); for Hungary by Fazekas (2002, pp. 177-185); for Poland by World Bank (2001, Tab. 3.9) for the years 1990-'00; Newell and Pastore (2000) for the years 1994-’97; and Rutkowski and Przybila (2002, pp. 157-160) for the years 1993-‘01; for Romania by Kállai and Traistaru (2001, pp. 5-7) for the years 1992-'95.

${ }^{3}$ Elhorst (2003) contains a detailed survey of the literature on regional unemployment differentials in mature market economies. He also sketches a model that is able to explain regional unemployment differentials. This model is a system of four equations consisting of participation, migration, commuting, the wage curve, employment growth and unemployment. It has characteristics of the model in Blanchard and Katz (1992) and Decressin and Fatas (1995), but is much larger, in as much as previous models only considered three equations. Moreover, previous models did not contain any exogenous explanatory variables. The problem to estimate Elhorst's model is, of course, data availability.

${ }^{4}$ The OST literature started in the early 1990s to address the issue of the speed at which the former socialist economies should move to market capitalism. For surveys, see Roland (2000), Boeri (2000), Pastore and Verashchagina, (2004).

${ }^{5}$ Discussion of these alternative approaches, however, is beyond the scope of this paper.

${ }^{6}$ This definition is so general that it applies to almost all transition countries. It also applies to China, where economic transition has not engendered any significant change in the political regime. It does not apply to Cuba, where reforms have not induced any significant change in the allocation system, which is still based on central planning.

${ }^{7}$ Given to its simplicity and clarity, the Aghion and Blanchard (1994) model has become very popular in the transition literature. Detailed presentations of the model and discussions of its implications can be found in handbooks on economic transition (Blanchard, 1997, Ch. 2; and Roland, 2000, Ch. 5), or in some recent studies (Boeri, 2000, Ch. 1; Pastore and Verashchagina, 2004).

${ }^{8}$ In his discussion of the benchmark OST model, Kehoe (1994, p. 323) critically comments that "in essence, it is an adjustment cost story. Specifically, it is basically a simple model of sectoral adjustment with a few bells and whistles thrown in to make it more consistent with the micro realities of Poland".

${ }_{9}$ Aghion and Blanchard (op. cit., p. 296) admit that, already in the early stages of transition, numerous hirings were made directly from state firms, rather than from unemployment. Nonetheless, they do not consider this simplification to be misleading. Conversely, according to Boeri (2000), assuming a fixed labour supply, neglecting the role of flows to inactivity and of job-to-job moves would be a weakness of the benchmark model. This point will be developed in a following section.

${ }^{10}$ Aghion and Blanchard (op. cit.) also consider the case of endogenous separations (decided by the workers in the state sector), but this case is not considered here. As noted in one of the following sections, 
Lehmann and Walsh (1999) study the case with endogenous separations to explain regional unemployment differentials.

${ }^{11}$ In fact, the high degree of job and worker turnover typical of private activities is well documented in the transition literature (see e.g. Adamchik and King, 1999), which suggest that the private sector found it extremely difficult to emerge during the transition period.

12 In Aghion and Blanchard (1994, p. 297), unemployment benefits are a proxy of various burdens on the state budget, such as the pensions to pay for early retirements, the lack of state funds to finance public investment, the introduction of political uncertainty which reduces the contribution of direct investment from abroad: all factors that cannot be explicitly considered in the model's setup.

${ }^{13}$ Wojewòdztwo is the Polish word for region, which was translated in English as: 'voivodship'. In fact, rather than regions, voivodships resemble English counties (NUTS3 level), considering that their number (49) is rather large compared to the country's population (38 million).

${ }^{14}$ The index is: $I=0.5\left(\left|s_{i, t}-s_{i, 0}\right|\right)$, where $s_{i, t}$ is the share of employment in industry $i$ at time $t$ and $i=1,2, \ldots, n$.

${ }^{15}$ The degree of aggregation is extremely important, because a sizeable part of worker reallocation may occur within industries in a way not necessarily correlated to changes between industries. Using 32 industries does not ensure that aggregation issues are completely controlled for.

${ }^{16}$ Layard et al. (1991) calculated average annual percentage rates for a number of countries over the decades from the 1950s to the 1980s. On average, on the basis of eight sectors of industry, these rates were $1 \%$, and none of them was higher than $2.2 \%$. Part of the difference is due to the degree of aggregation and to the length of time on which changes in shares were computed. However, this finding confirms the high degree of industrial turbulence in Poland.

17 Elhorst (2003) reports that some, if not all the studies using various indices of industry concentration found a significant positive effect on local unemployment in mature market economies.

${ }^{18}$ For a more systematic assessment of labour market rigidity/flexibility in CEECs, see Riboud et al. (2002), Svejnar (2002b). The World Bank ranks 145 countries, including transition countries, by various indices of labour market flexibility. The results are available at: http://rru.worldbank.org/DoingBusiness/. They show that CEECs are not very much dissimilar from EU countries under this respect.

${ }^{19}$ There are various theories that could explain why this might be the case. See e.g. Blanchflower and Oswald (1994) and Card (1995).

${ }^{20}$ However, several authors note that the decline in long-distance migration was accompanied by an increasingly high degree of commuting linked to urban-suburban migration with no employment change in the Czech Republic (Burda and Profit, 1996; Fidrmuc and Huber, 2003) and Hungary (Cseres-Gergely, 2002).

${ }^{21}$ Rutkowski and Przybila (2002, p. 159) note that special contributions are granted to farmers in Poland, which further reduces the incentive to move or commute.

\section{References}

Abraham, K. G. and L. F. Katz (1986), “Cyclical Unemployment: Sectoral Shifts or Aggregate Disturbances?”, Journal of Political Economy, 94(3): 507-522.

Adamchik, V. and A. E. King (1999), "The Impact of the Private Sector Development on Unemployment, Labour Force Reallocation and Labour Market Flows in Poland”, paper presented at the annual meetings of the ACES, New York, NY, January 2-4.

Aghion, P. and O. Blanchard (1994), "On the Speed of Transition in Central Europe”, NBER

Macroeconomics Annual, 283-320. 
Barbone, L., D. J. Marchetti and S. Paternostro (1999), “The Early Stages of Reform in Polish Manufacturing. Structural adjustment, Ownership and Size”, The Economics of Transition, 7(1): 157-177.

Berg, A. (1994), “Does Macroeconomic Reform Cause Structural Adjustment? Lessons from Poland”, Journal of Comparative Economics, 18(3): 376-409.

Blanchard, O. J. (1997), The Economics of Post-Communist Transition, Clarendon Press, Oxford.

Blanchard, O. J. and L. F. Katz (1992), "Regional Evolutions”, Brookings papers on Economic Activity, 1: 1-75.

Blanchard, O. J. and M. Kremer (1997), “Disorganisation”, Quarterly Journal of Economics, November, 112(4), 1091-1126.

Blanchard, O. J., S. Commander and F. Coricelli (1994), "Unemployment and the Labour Market in Eastern Europe”, OECD, Unemployment in Transition Countries: Transient or Persistent?, Paris, 59-79.

Blanchflower, D. G. and A. J. Oswald (1994), The wage curve, MIT Press, Cambridge, MA.

Blanchflower, D. G. (2001), “Unemploymemt, Well-being and Wage curves in Eastern and Central Europe", Journal of the Japanese and International Economies, 15(4): 364-402.

Boeri, T. (1994), “«Transitional» Unemployment”, Economics of Transition, 2(1): 1-25.

Boeri, T. (1997), "Labour Market Reforms in Transition Economies", Oxford Review of Economic Policy, 103(2): 126-140.

Boeri, T. (1998), "Labour Market Flows in the Midst of Structural Change”, in Commander, S. (op. cit.).

Boeri, T. (2000), Structural Change, Welfare Systems, and Labour Reallocation. Lessons from the Transition of Formerly Planned Economies, Oxford University Press, Oxford.

Boeri, T. and K. Terrell (2002), "Institutional Determinants of Labour Reallocation in Transition”, Journal of Economic Perspectives, 16(1): 51-76.

Boeri, T. and Scarpetta S. (1995), "Dealing with a Stagnant Pool: Policies for Coping with Long-Term Unemployment in Central and Eastern Europe”, in Dobrinsky R. And Landesmann M. (ed.), Transforming Economies and European Integration, Edward Elgar, Aldershot. 
Boeri, T. and S. Scarpetta (1996), "Regional Mismatch and the Transition to a Market Economy”, Labour Economics, October, 3(3): 233-254.

Boldrin, M., F. Canova (2001), "Inequality and Convergence in Europe's regions. Reconsidering European Regional Policy”, Economic Policy, 32: 205-245.

Boldrin, M. and F. Canova (2003), "Regional Policies and EU Enlargement”, in B. Funck and L. Pizzati (2003, eds.), European Integration, Regional Policy, and Growth, World Bank, Washington, D.C.

Bornhorst, F. and S. Commander (2004), "Regional Unemployment and its Persistence in Transition Countries”, IZA DP, n. 1074, March.

Borensztein, E., D. G. Demekas and J. Ostry (1993), “An Empirical Analysis of the Output Declines in Three Eastern European Countries”, IMF Staff Papers, 40(1): 1-31.

Borensztein, E. and J. Ostry (1992), "Structural and Macroeconomic Determinants of the Output Decline in Poland: 1990-91”, IMF Working Papers, n. 86, October.

Burda, M.C. and S. Profit (1996), "Matching across Space: Evidence on Labour Mobility in the Czech Republic”, Labour Economics, 3(3): 255-78

Caétano, J., A. Galero, E. Vaz, C. Vieira, I. Vieira (2002) "The Eastward Enlargement of the Eurozone Trade and FDI”, Ezoneplus Working Paper No. 7, August, Fifth Framework Programme 2001-2004 European Commission Research Project HPSE-CT-2001-00084

Card, D. (1995), “The Wage Curve: A Review”, Journal of Economic Literature, 33(2): 785799.

Cazes, S. and A. Nesporova (2001), "Labour Market Flexibility in the Transition Countries. How Much is too Much?”, International Labour Review, 140(3): 293-325.

Cazes, S. and S. Scarpetta (1998), "Labour Market Transitions and Unemployment Duration: Evidence from Bulgarian and Polish Micro-Data”, Economics of Transition, 6(1): 113-144.

CEPR (1990), Monitoring European Integration. The Impact of Eastern Europe, London.

Cseres-Gergely, Z. (2002), "Residential Mobility, Migration and Economic Incentives: The Case of Hungary in 1990-99”, Budapest working papers, n. 7.

Decressin, J. and Fatàs, A. (1995), “Regional Labour Market Dynamics in Europe”, European Economic Review, 39(9): 1627-1655. 
Dewatripont, M. and G. Roland (1992), "The virtues of Gradualism and Legitimacy in the Transition to a Market Economy”, Economic Journal, 102(411): 291-300.

Duffy, F. and P. P. Walsh (2000), “A Regional Analysis of Wage Determination in Poland”, LICOS discussion paper, n. 87.

Duffy, F. and P.P. Walsh (2001), "Individual Pay and Outside Options: Evidence from the Polish Labour Force Survey”, IZA discussion paper, n. 295.

Dupuch, S., H. Jennequin and E.M.Mouhoud (2004), "EU Enlargement: What does it Changes for the European Economic Geography”, Revue de l'OFCE, Special Issue, April, 241-274.

Elhorst, J. P. (2003), “The Mystery of Regional Unemployment Differentials. Theoretical and Empirical Explanations”, Journal of Economic Surveys, 17(5): 709-748.

Eurostat (2002), “Foreign Direct Investment within the candidate countries”, Statistics in Focus, Theme 2, 55/2002.

Eurostat (2004a), "Regional Unmployment in the European Union and Candidate Countries in 2003”, Statistics in Focus, 3: 1-8.

Eurostat (2004a), “Regional Unemployment in the EU25”, News Release, 133:1-8.

Faggio, G. and J. Konings (2003), "Job Creation, Job Destruction and Employment Growth in Transition Countries”, Economic Systems, 27(2): 129-154.

Falvey, R. (1981), “Commercial Policy and Intra-Industry Trade”, Journal of International Economics, 11(4): 495-511.

Falvey, R. and H. Kierzkowski (1987), "Product Quality, Intra-Industry Trade and Im(pefect) Competition”, in H. Kierzkowski, Protection and Competition in International Trade (ed.), Oxford, Blackwell.

Fazekas, K. (2000), “Impact of Foreign Direct Investment Inflows on Regional Labour Markets in Hungary”, SOCO Project Paper 77c, Vienna: Institute for Human Sciences.

Fazekas, K. (2002), "Regional Disparities in Unemployment in Central and Eastern Europe: The Case of Hungary”, in B. Funck and L. Pizzati (eds.), op. cit., Chapter XV, 176-196. Fazekas, K. (2003), "Effects of Foreign Direct Investment on the Performance of Local Labour Markets. The Case of Hungary”, Budapest working papers, n. 3.

Ferragina, A.M. (2004), “Catching up of Candidate Countries: Factors, Skills and Quality”, University of Rome "Tor Vergata” and CNR, mimeo. 
Ferragina, A. M. and F. Pastore (2005), "Factor Endowment and Market Size in EU-CEE Trade. Would Human Capital Change the Actual Quality Trade Patterns?”, Eastern European Economics, 43(1): 3-36.

Fidrmuc, J. (2004), “Migration and Regional Adjustment to Asymmetric Shocks in Transition Economies”, Journal of Comparative Economics, 32(2): 230-247.

Fidrmuc, J. and P. Huber (2003), "Where have all the Migrants Gone? Reconciling Falling Migration Rates with Rising Regional Disparities during Transition”, ECARES, Université Libre de Bruxelles, typescript.

Fontagnè L., Freudenberg M. and Peridy, N. (1998), "Intra-industry trade and the Single Market: Quality Matters”, CEPR Discussion Paper, n. 1953.

Frankel, J. and Rose A. (1998), "The Endogeneity of Optimum Currency Criteria”, The Economic Journal, vol. 108(449): 1009-1025.

Freudenberg, M. and Lemoine, F. (1999), "Central and Eastern European Countries in the International Division of Labour in Europe”, CEPII WP, n. 5.

Funck, B. and L. Pizzati (2002, eds.), Labour, Employment and Social Policy in the EU Enlargement Process. Changing Perspectives and Policy Options, World Bank, Washington, D.C.

Góra, M. and Lehmann H. (1995), "How Divergent is Regional Labour Market Adjustment in Poland?”, OECD (op. cit.).

Gorzelak, G. (1996), The Regional Dimension of Transformation in Central Europe, Jessica Kingsley Publishers, London.

Greenaway, D. and J. Torstensson (2000), "Economic Geography, comparative advantage and trade within industries: evidence from the OECD”, Journal of Economic Integration, 15(2): 260-180.

Helpman, E. (1981), "International Trade in the Presence of Product Differentiation, Economies of Scale and Monopolistic Competition. A Chamberlin-Heckscher-Ohlin Approach”, Journal of International Economics, 11(3): 305-340.

Helpman, E. and P. Krugman (1985). Market Structure and Foreign Trade, MIT Press.

Herzog, E.W. (2000), "Plant Scale, Industry Agglomeration and the Outlook for Regional Employment in Central European Economies”, Journal of Regional Science, 40(3): 499-521. 
Huber, P. (2004), “Intra-National Labour Market Adjustment in Candidate Countries”, Journal of Comparative Economics, 32(2): 248-264.

Iara, I and I. Traistaru (2004), “How Flexible are Wages in EU Accession Countries?”, Labour Economics, 11(4): 431-450.

Kállai, E. and I. Traistaru (2001), “Characteristics and Trends of Regional Labour Markets in Transition Economies: Empirical Evidence for Romania”, LICOS DP, n. 72.

Kehoe P. J. (1994), “Comment to: «On the Speed of Transition in Central Europe»”, NBER Macroeconomics Annual, 320-328.

Kertesi, G. (2000), "Migration and Commuting: Two Potential Forces Reducing Regional Inequalities in Economic Opportunities?", SOCO Project Paper 77a, Vienna: Institute for Human Sciences.

Kertesi, G. and J. Köllo (2003), “The Employment Effects of Nearly Doubling the Minimum Wage - The Case of Hungary”, Budapest Working Papers, n. 6.

Konings, J., H. Lehmann and M. Schaffer (1996), "Job Creation and Job Destruction in a Transition Economy: Ownership, Firm Size, and Gross Job Flows in Polish Manufacturing 1988-1991”, Labour Economics, 3(3): 299-317.

Kornai, J. (1992), The Socialist System. The Political Economy of Communism. Oxford, Oxford University Press.

Krajnyàk, K. and M. Sommer (2004), Czech Republic, IMF country Report, n. 4/265, August.

Krugman, P. R. (1980), "Scale Economies, Product Differentiation and the Pattern of Trade”, American Economic Review, 70(5): 950-959.

Krugman, P. R. and T. Venables (1995), "Globalisation and the Inequality of Nations", Quarterly Journal of Economics, 110(4): 857-880.

Landesmann, M. (2002), "Spatial Disparities and Labour Mobility. Discussant Notes”, in B. Funck and L. Pizzati (eds.), op. cit., 232-234.

Landesmann, M. (2003), Structural Features of Economic Integration in an Enlarged Europe: Patterns of Catching-up and Industrial Specialisation, European Commission, DG Economy and Finance, Economic Paper, n. 181.

Landesmann, M. and J. Burgstaller (1998), "Vertical Product Differentiation in EU Markets: the Relative Position of East European Producers”, Russian and Eastern European Finance and Trade, 34(1): 32-78. 
Layard, R., Nickell S. and Jackman R. (1991) Unemployment, Oxford University Press, Oxford.

Lehmann, H. and P. P. Walsh (1999), “Gradual Restructuring and Structural Unemployment in Poland: A Legacy of Central Planning”, LICOS DP, n. 78, Katholieke Universiteit Leuven.

Lilien, D. M. (1982), "Sectoral Shifts and Cyclical Unemployment”, Journal of Political Economy, 90(4): 777-793.

Markusen, J.R. (1995), “The Boundaries of Multinational Enterprises and the Theory of International Trade”, Journal of Economic Perspectives, 9(2): 169-189.

Marston, S. T. (1985), “Two Views of the Geographic Distribution of Unemployment”, The Quarterly Journal of Economics, 100(1): 57-79.

Neven, D. (1995), “Trade Liberalisation with Eastern Nations: How Sensitive?”, in Faini, R. and R. Portes (ed.), European Union Trade with Eastern Europe: Adjustment and Opportunities, CEPR.

Newell, A. (2005), "Skill Mismatch and Regional Unemployment in Poland”, in Caroleo, F.E. e S. Destefanis (eds.), Regions, Europe and the labour market. Recent problems and developments, Physica Verlag, Heidelberg.

Newell, A. and F. Pastore (1999), “Structural Change and Structural Unemployment in Poland”, Studi Economici, 69(3): 81-100.

Newell, A. and F. Pastore (2000), "Regional Unemployment and Industrial Restructuring in Poland”, IZA DP, n. 194, November.

Newell, A., F. Pastore and M. Socha (2002), “Comparative Advantages, Job Destruction and the Regional Pattern of Polish Unemployment”, Acta Oeconomica, 52(2): 187-204.

OECD (1995), “The Regional Dimension of Unemployment in Transition Countries. A Challenge for Labour Market and Social Policies, Paris.

Overman H.G. and D. Puga (2002), "Regional Unemployment Clusters”, Economic Policy, 17(34): 115-148.

Pastore, F. (2004), "Regional Unemployment Persistence in Poland. A survey of the evidence and some insights from the literature" (2004), Current Politics and Economics of Russia, Eastern and Central Europe, 16(3): 97-116.

Pastore, F. and A. Verashchagina (2004), "Slow and Steady Wins the Race? An Appraisal of Ten Years of Economic Transition”, Economia Politica, 21(3): 437-458. 
Puga, D. (1999), “The Rise and Fall of Regional Inequalities”, European Economic Review, 43(2): 303-334.

Puga, D. (2002), “European Regional Policy in Light of Recent Location Theories”, Journal of Economic Geography, 2(4): 373-406.

Riboud, M., C. Sánchez-Páramo C. and C. Silva-Jáuregui (2002), “Does Eurosclerosis Matter? Institutional Reform and Labour Market Performance in Central and Eastern European Countries in the 1990s”, The World Bank, Social Protection discussion paper, n. 202, March.

Roland, G. (2000), Transition and Economics. Politics, Markets and Firms, The MIT Press.

Rutkowski, J. and M. Przybila (2002), “Poland: Regional Dimensions of Unemployment”, in B. Funck and L. Pizzati (eds.), op. cit., Chapter XIV, 157-175.

Scarpetta, S. (1995), "Spatial Variations in Unemployment in Central and Eastern Europe: Underlying Reasons and Labour Market Policy Options”, in OECD (op. cit.), pp. 27-74.

Scarpetta, S. and Hüber P. (1995), "Regional Economic Structures and Unemployment in Central and Eastern Europe. An Attempt to Identify Common Patterns”, in OECD (op. cit.).

Sibley C.W. and P.P. Walsh (2002), "Earnings Inequality and Transition: A Regional Analysis of Poland”, IZA DP, n. 441.

Simon, C. J. (1988), “Frictional Unemployment and the Role of Industrial Diversity”, Quarterly Journal of Economics, 103(4): 715-728.

Simon, C. J. and C. Nardinelli (1992), "Does Unemployment Diversity always Reduce unemployment? Evidence from the Great Depression and After”, Economic Enquiry, 30(2): 384-397.

Suedekum, J. (2003), “Increasing Returns and Spatial Unemployment Disparities”, University of Goettingen, discussion paper, n. 117, April.

Svejnar, J. (2002a), “Transition Economies: Performance and Challenge”, Journal of Economic Perspectives, February, 16(2): 3-28.

Svejnar, J. (2002b), "Labour Market Flexibility in Central and Eastern Europe”, WDI Discussion Paper, n. 496, August. 
Traistaru, I. and B. Pauna (2002), “Economic Integration, Regional Specialisation and Location of Industrial Activity in Romania”, ZEI, mimeo.

UNCTAD (various years), World Investment Report.

Venables, T. (1996), “Equilibrium Locations of Vertically Linked Industries”, International Economic Review, 37(2): 341-359.

Walsh, P.P. (2003), “The Cyclical Pattern of Regional Unemployment Flows in Poland", Economic Systmes, 27(2): 155-169.

World Bank (2001), Poland-Labor Market Study: The Challenge of Job Creation, World Bank Country Study, March.

World Bank (2004), Poland. Growth, Employment and Living Standards in Pre-Accession Poland, Report n. 28233. 